\title{
The Relations between Enablers of the European Foundation for Quality Management and Its Results at Palestinian Central Bureau of Statistics
}

\author{
Shibli Ismael Morshed Swaitti \\ Business - Faculty of Administrative and \\ Economic Sciences \\ $\mathrm{Al}$ - Quds Open University - Palestine \\ sswaitti@qou.edu
}

\author{
Ahmad Saif-Edden Abd-Alhafiz Jallad \\ Office of Assistant Under-secretary for \\ Administrative, Financial \& IT Affairs \\ Palestinian Central Bureau of Statistics \\ ajallad@pcbs.gov.ps
}

Received 3/9/2019

Accepted 15/10/2019

\begin{abstract}
:
The study aims to shed light on the relations between enablers of The European Foundation for Quality Management (EFQM) and its results at Palestinian Central Bureau of Statistics (PCBS). The study adopts the analytical descriptive approach that is applied at PCBS according to a regular random sample of 100 employees to whom the questionnaire is distributed, and the data is analyzed according to the statistical analysis program (SPSS).

The study found out that there is a relation between EFQM's enablers combined with its results at PCBS where the strength of the relation is $86 \%$; moreover, it also shows that there is a statistical relation between leadership, partnerships, resources, processes, products, and services with EFQM's model results and that there is no relation between strategy and staff with EFQM's model results where each enabler is associated with the results with a percentage of $(78 \%)$ to enable operations, products, services, partnerships, and resources of (75\%), (64\%) for leadership, (61\%) for staff, and (56\%) for strategy.

The results highlight a number of points of strength; most importantly, that PCBS is keeping pace with the rapid development of technology in data collection to support the credibility of its statistical outputs; in addition to this, PCBS is known for its high levels of planning and review of its work results and that PCBS administrations supports the areas of excellence, creativity, and opportunities for improvement of its staff as well as supporting PCBS's strategy through a set of performance indicators related to society's needs and measurement of impressions.

The study came out with recommendations, the most important of which is PCBS' efforts towards achieving the second level of the European institutions "recognized for excellence" and updating the European quality excellence model in light of the rapid technological developments and the modern management information systems.
\end{abstract}

Keywords: Enablers, Results, Excellence Model of the European Foundation for Quality Management, Performance, Excellence. 


\section{العلاقة بين ممكنات نموذج التميز للمؤسسة الأورويية لإدارة الجودة ونتائجه في الجهاز المركزي للإحصاء القلسطيني (EFQM)}

\author{
أحمد سيف الدين عبد الحفيظ جلاد \\ مكتب الوكيل المساعد للشئون الإدارية \\ الجهاز المركزي للإحصاء الفلسطيني \\ ajallad@pcbs.gov.ps
}

\author{
شبلي اسماعيل مرشد سويطي \\ الأعمال - العلوم الإدارية والاقتصادية \\ جامعة القس المفتوحة - فلسطين \\ sswaitti@qou.edu
}

قبول البحث

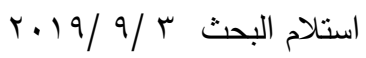

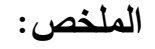

هدفت الدراسة إلى بيان العلاقة بين ممكنات نموذج التميز للمؤسسة الأوروبية لإدارة الجودة (EFQM) ونتائجه في الجهاز المركزي

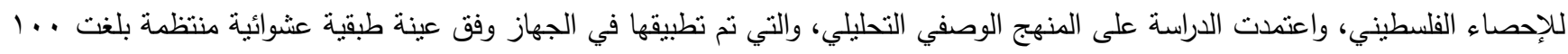

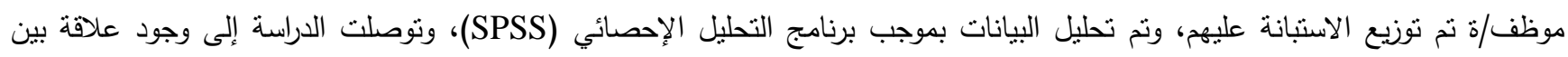

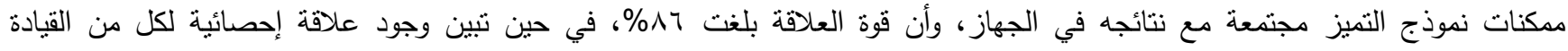

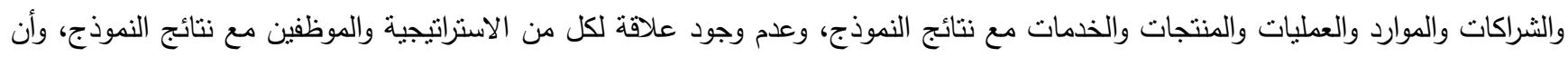

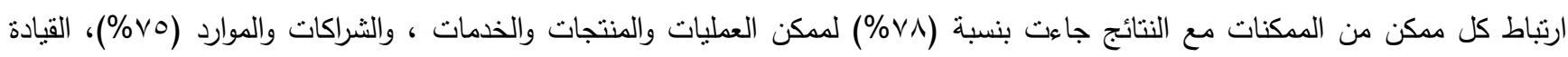

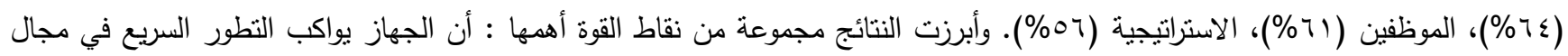

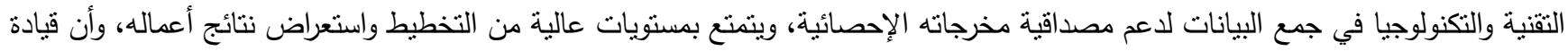
الجهاز تدعم مجالات التميز والإبداع، وفرص التحسين تتلخص بتمكين الموظفين بشكل أكبر لإطلاق كامل إمكانياتهم وقدراتهم، ودعم استراتيجية

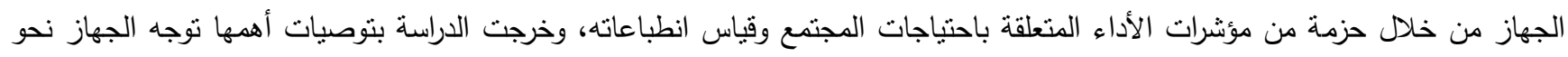

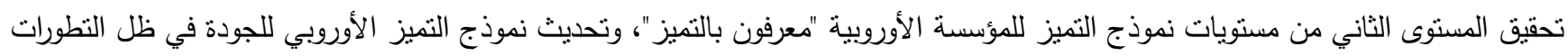
التكنولوجية الهائلة ونظم المعلومات الإدارية الحديثة. الكلمات المفتاحية: ممكنات، ننائج، نموذج النمبز للمؤسسة الأوروبية لإدارة الجودة، الأداء، التميز.

وقد ظهرت مفاهيم نماذج التميز كإطار عام للجهود والنشاطات

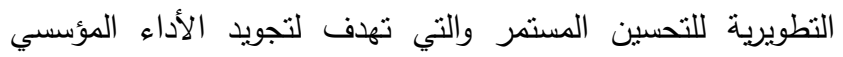
ابتداءً من نموذج (Deming) للتميز والذي ظهر في عقد الخمسينات

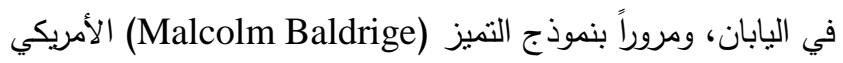
والذي ظهر في عقد الثمانيات، وحتى ظهور نموذج التميز للمؤسسة الإنة

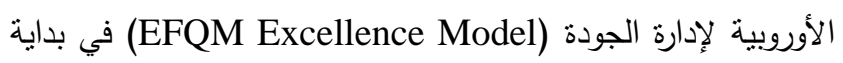
التسعينات، وتم الإعلان الرسمي عن نموذج التميز للمؤسسة الأوروبية

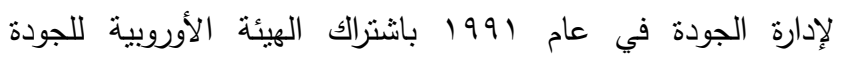

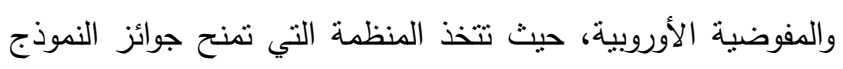

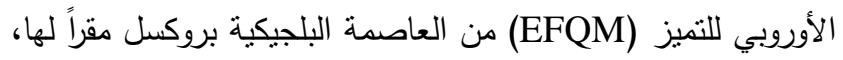

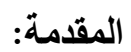

لقد بات السعي للتمبز وتطبيق ممارسات الجودة في المنظمات على مختلف أنواعها واشكالها وتبعانها نهجاً تحذوه المنظمات من أجل مواجهة التحديات العالمية المعاصرة في ظل العولمة التي يشهدها

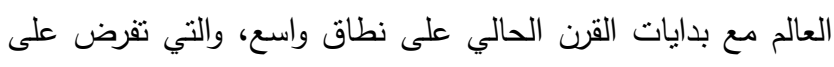

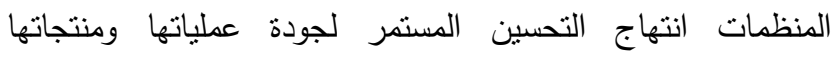
وتخفيض تكاليفها، وأصبح لا بد من الاعتماد على أفضل الممارسات

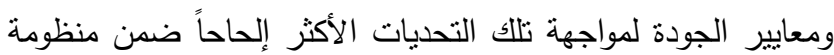
الأعمال، وذلك لضمان استمرارية وكفاءة المنظمات بممارسة أعمالها في ظل بيئة الأعمال الحالية. 
وأجهزة منطورة من أهم أجهزة الدولة في عصر تعتبر فيه البيانات

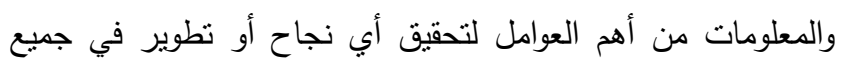

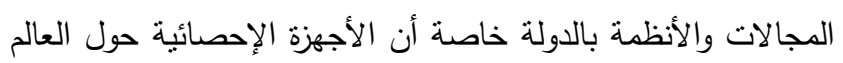

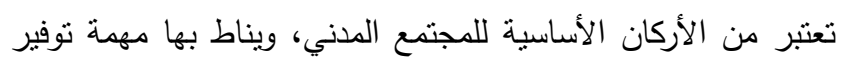

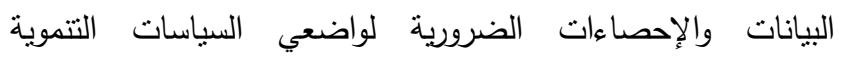
والتخطيطية، وتتولى الحكومات توفير كافة الوسائل المادية والمعنوية لواتية من أجل إنجاح مهام أجهزة الإحصاء في دولها، وتمكينها من القيام بمهامها التقليدية بشكل موضوعي وفعال وعلمي(10).

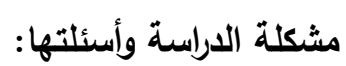

إن إجراء التقييم وفق نموذج التميز للمؤسسة الأوروبية لإدارة

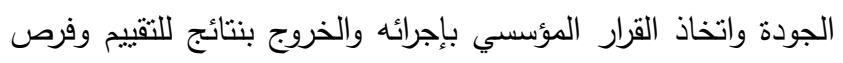

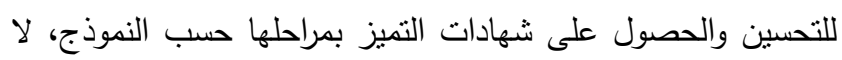
تكفي لمعرفة العلاقة السبيية بين ممكنات النموذج وارتباطها بالنتائج الحقيقية التي يوضحها نموذج التميز للمؤسسة الأوروبية لإدارة

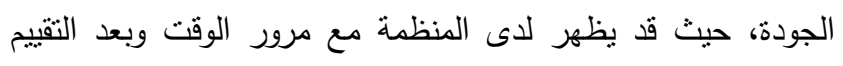

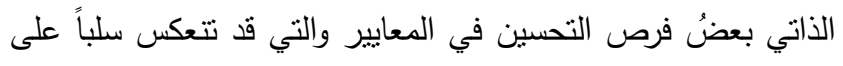

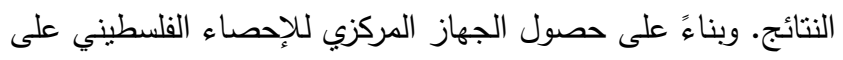

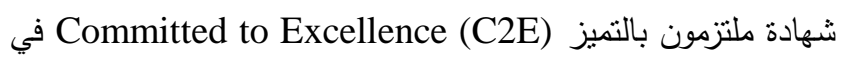
منتصف عام Y I ا ب مع ثلاث مؤسسات فلسطينية أخرى، وعدم قيام

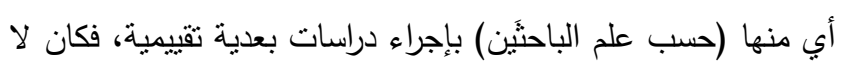

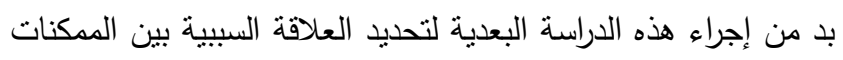

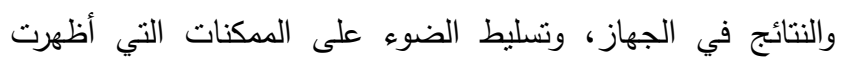
فرصاً للتحسين في النتائج، من أجل دعم المدكنات التي تعتبر نقاط قوة والتي قد نسهم في تحقيق نتائج باهرة، وفي نفس الوقت الوت القيام

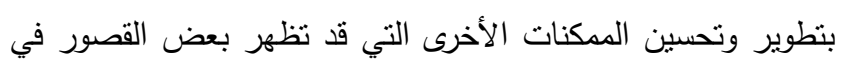
النتائج، وعليه فقد جاءت هذه الدراسة للإجابة على التساؤلات الآتية: ما مدى نوافر مدكنات نموذج (EFQM) بعناصره (القيادة،

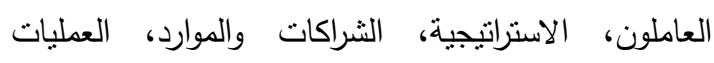
والمنتجات والخدمات) في الجهاز المركزي للإحصاء الإن العرات الفلسطيني؟ ما العلاقة بين ممكنات نموذج (EFQM) ونتائجه المتمنلة

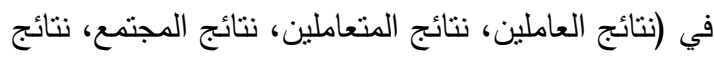

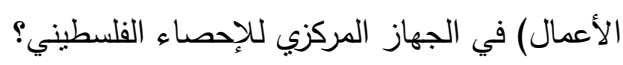

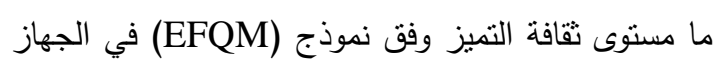

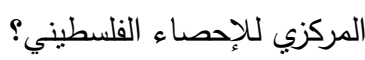
ما هي رؤية الجهاز المركزي للإحصاء الفلسطيني لتحقيق لإحكيق

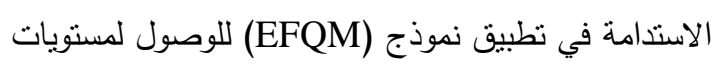

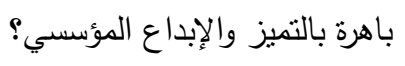

وتضم أعضاء لأكثر من . V. منظمة ينتشرون في شتى أنحاء

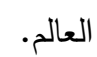

يهدف نموذج التميز للمؤسسة الأوروبية لإدارة الجودة

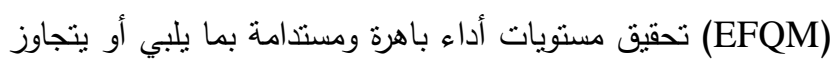

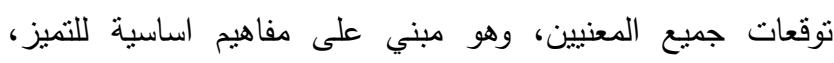

ومعايير ينم التقييم من خلالها باستخدام منطق رادار (RADAR). كما ويشار للنموذج أحياناً بنموذج المؤسسة الأوروبية لإدارة

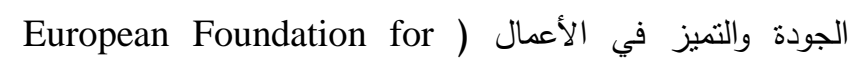
Quality Management Model for Business (v) $^{(\text {Excellence }}$ وتتطلب إدارة التميز المؤسسي إحداث تغيير جذري في المناخ

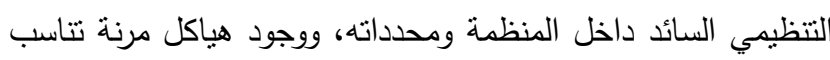

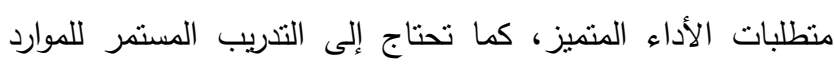

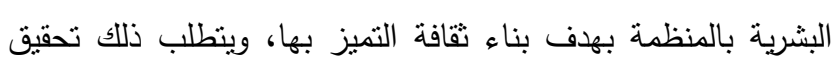

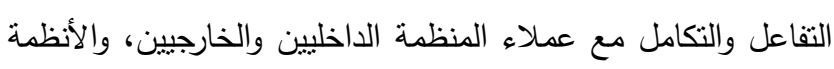

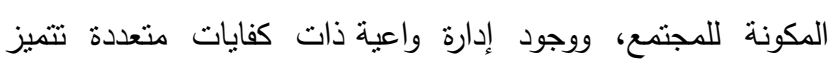
بالمرونة، والقدرة على التكيف مع طبيعة العصر ومتغيراته، والقدرة على تحليل وإدراك العلاقات واتخاذ القرارات(^). إنّ نموذج التميز للمؤسسة الأوروبية لإدارة الجودة (EFQM)

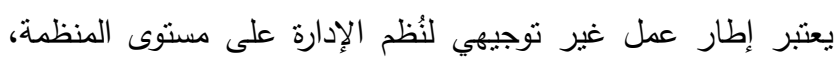

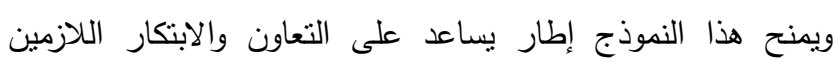

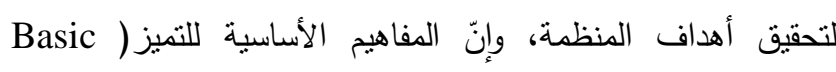
تمثل المبادئ الأولية والقاعدة (Concepts of Excellence

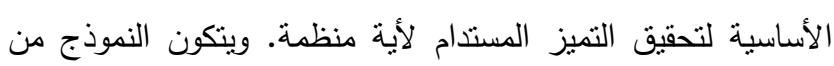

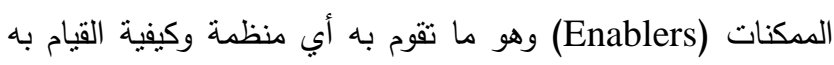
ويشمل (القيادة، العاملون، الاستراتيجية، الشراكات والموارد، العمليات

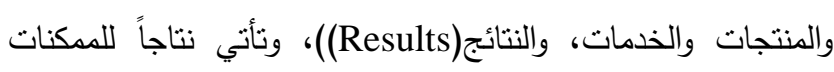

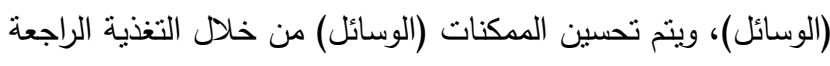
من النتائج، والنتائج حسب ولخب النموذج هي: (لنائج العاملين، نتائج

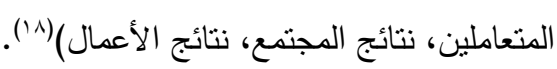

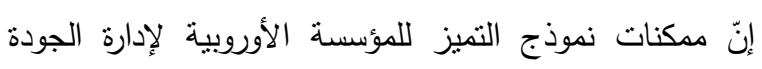
ونتائجه في المنظمات هو مقياس عالمي يشير إلى تقدم

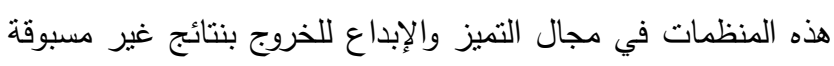

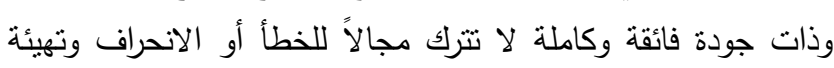

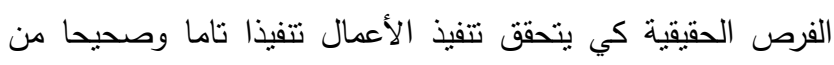
المرة الأولى من أجل التفوق على منافسيها(`).

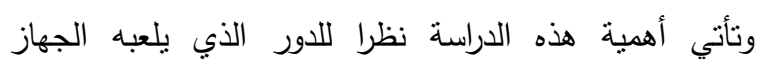
المركزي للإحصاء الفلسطيني والذي بدأ التخطيط لإنشائه في أوائل عام ب991، ويعتبر بما لديه من إمكانات بشرية وخبرات فنبة متميزة 
إبراز الأهمية الحقيقية للنموذج كونه قد طبق في فلسطين حديثاً خلال الفترة الماضية على أربع منظمات حكومية،

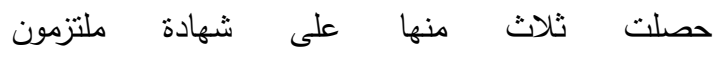
بالتميز Committed to Excellence (C2E) من بينها الجهاز المركزي للإحصاء الفلسطيني.

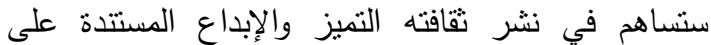
نموذج التميز للمؤسسة الأوروبية لإدارة الجودة (EFQM) كنموذج ناجح في المنظمات.

إثراء المكتبة العربية والعالمية ببحث مستجد ورائد حول هذات

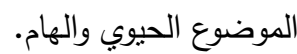
نتائج هذه الدراسة قد بستند إليها باحثنون آخرون في إجراء دراسات مستقبلية وذلك لندرة تتاول هذا الموضوع في بالتي فلسطين بشكل خاص والدول العربية بشكل عام.

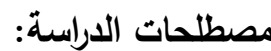

نموذج التميز للمؤسسة الأوروبية لإدارة الجودة: هو إطار عمل غير توجيهي لنُظم الإدارة على مسنوى المنظمة، ويمنح هذا

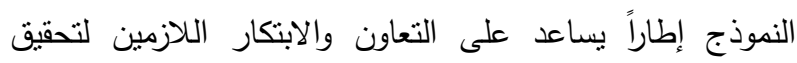

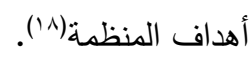

الممكنات: هو ما تقوم به أي منظمة وكيفية القيام به، وهم: القيادة، العاملون، الاستراتيجية، الثراكات والموارد، العطليات

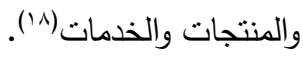
النتائج: هي تأتي نتاجاً للمدكنات (الوسائل)، ويتم تحسين المكنات (الوسائل) من خلال التغذية الراجعة من النتائج، والنتائج حسب النموذج هي: نتائج العاملين، نتائج المتعاملين، نتائج

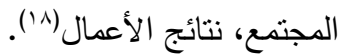
الجهاز المركزي للإحصاء القلسطيني: هو منظمة حكومية تأسست عام r99 أبعد إصدار رئيس السلطة الوطنية الفلسطينية آنذاك باسر عرفات قراراً بذلك، الجهاز المركزي للإحصاء الفلسطيني هو جهاز مسنقل قانونياً حيث يعمل حسب قانون

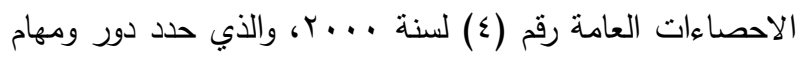
الجهاز، بحيث يتولى عملية إنشاء وتتفيذ وتطوير نظام إحصائي حديث وشامل وموحد ومنكامل ليكون أحد الأدوات التخطيطية الهامة للدولة في المجالات المختلفة(10). الإطار النظري:

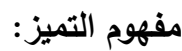

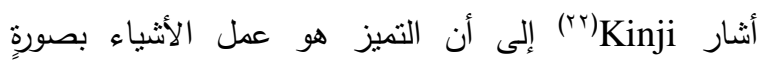
صحيحةٍ وبدرجةٍ عاليةٍ من الدقة والتفوق والاحتراف، وهو طريقة عملية لقياس الإنجازات من حيث معرفة رضا الزبائن والعاملين

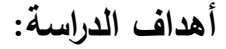

يتمثل الهدف الرئيس لهذه الدراسة بتحديد العلاقة بين ممكنات

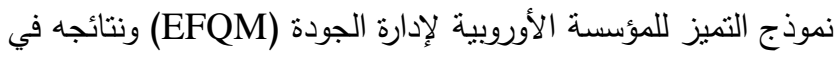
الجهاز المركزي للإحصاء الفلسطيني، وتتمثل الأهداف الفرعية لهذه لإنهان

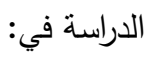

بيان مدى نوافر ممكنات نموذج (EFQM) والمتمنلة في (القيادة، العاملون، الاستراتيجية، الثراكات والموارد، العمليات والمنتجات والخدمات) في الجهاز المركزي للإحصاء الفلسطيني. بيان العلاقة بين ممكنات نموذج (EFQM) ونتائجه

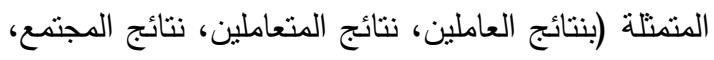

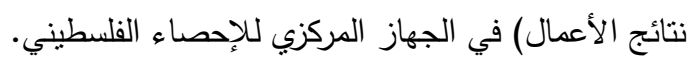
بيان واقع ثقافة التميز في الجهاز المركزي للإحصاء الفلسطيني وفق نموذج (EFQM). بيان رؤية الجهاز المركزي للإحصاء الفلسطيني للسعي للاستدامة في نطبيق نموذج (EFQM) للوصول إلى لئ ليان مستويات باهرة في التميز والإبداع المؤسسي. نمدئ

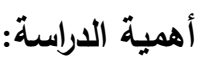

يتطلب موضوع العلاقة بين مدكنات نموذج التميز للمؤسسة

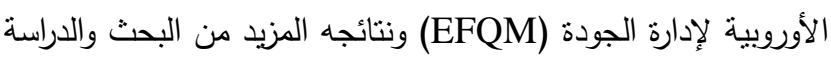

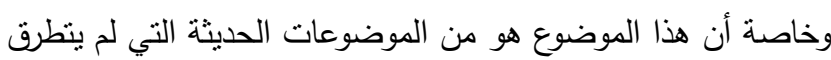
لها الباحثون في بحوثهم وبالتالي انحصرت أهمية الدراسة بالآتي: نسليط الضوء على نموذج التميز للمؤسسة الأوروبية لإدارة الجودة (EFQM) ونتائجه والذي يعتبر نموذجا رائدا في

$$
\text { منظمات الأعمال الحديثة. }
$$

تُعد هذه الدراسة من الدراسات الرائدة والقليلة جداً حول هذا

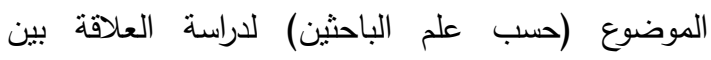

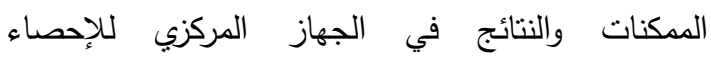
الفلسطيني، والتي نتكل معاً معايير نموذج التميز للمؤسسة

$$
\text { الأوروبية لإدارة الجودة. }
$$

ستستخلص الدراسة العلاقة السببية بين المككنات والننائج

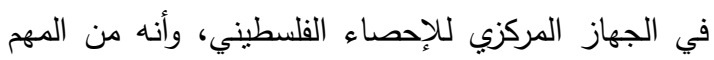

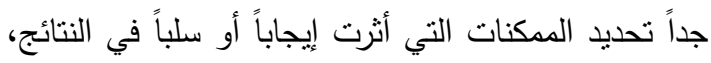

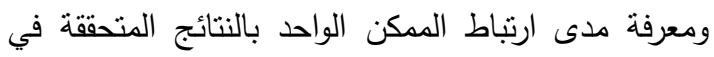
شتى الجوانب، حيث إنّ رحلة التميز لا تقاس بتحقيق إنجاز

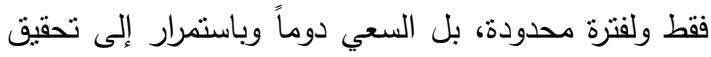
مسنتويات أعلى في الاداء بشكل مستدام. 
وذللك من خلال التركيز على القيادة والاستراتيجية والعاملين والموارد

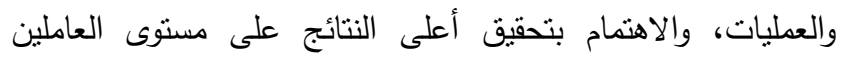

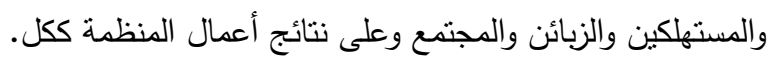

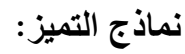

تعبر نماذج التميز عن مجموعة من المعايير المحددة سلفاً بحيث يكون لكل منها درجاتها الخاصة بها والتي تعتمد عليها

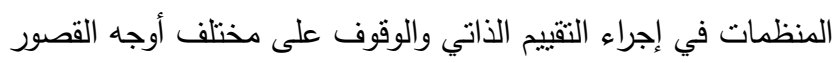

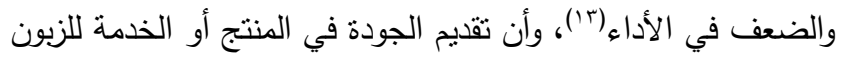

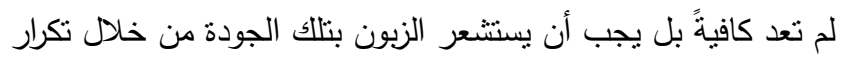
طلب السلعة أو الخدمة واعتراف منظمات محايدة سواء كانت محلية أو اقليمية أو دولية تختص بالجودة ليجري التعبير عن ذلك الاعتراف

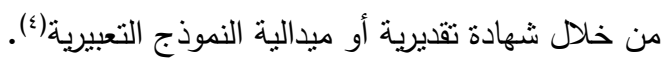

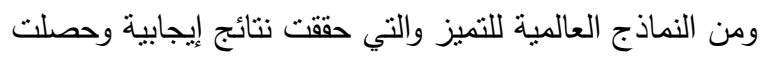
على شهرة واسعة، نموذج ديمنغ (DEMING).

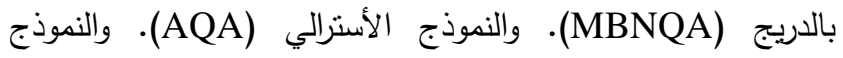
الكندي (CQA). والنموذج البرازيلي (BNQA). ونموذج التميز

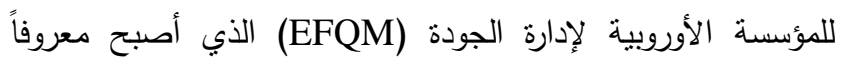

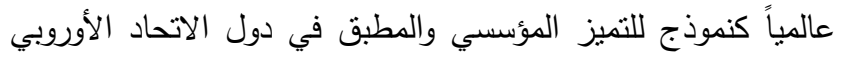

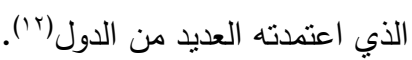

ويضيف الباحثان أن تطبيق نموذج (EFQM) للتميز لم يقتصر على دول الاتحاد الأوروبي فحسب، بل اكتسب شهرة عالمية

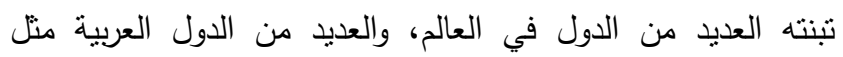

$$
\text { السعودية، الإمارات، دبي، قطر، الأردن، فلسطين. }
$$

\section{نموذج التميز للمؤسسة الأوروبية لإدارة الجودة (EFQM):}

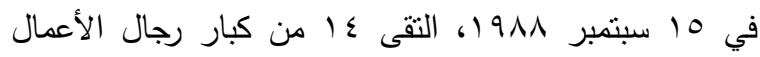

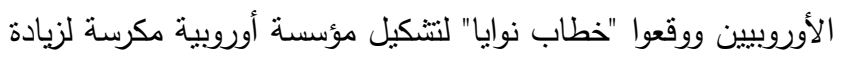
القدرة التتافسية للشركات الأوروبية، وتأسست الثركة في أكتوبر 1919، وفي عام 1991 نم بناء إطار ومفاهيم نموذج التميز وبعدها

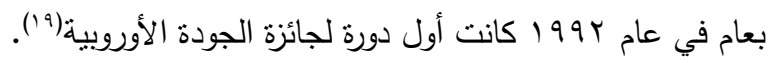
وتم بناء النموذج الخاص بالمؤسسة الأوروبية لإدارة الجودة

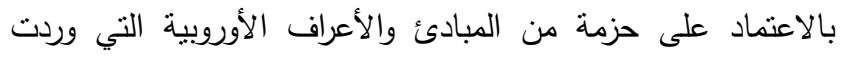

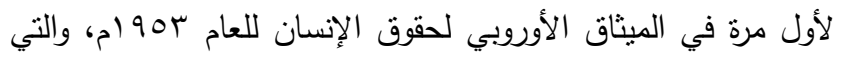

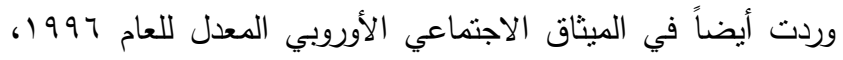

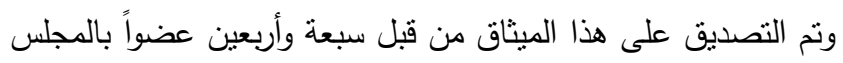

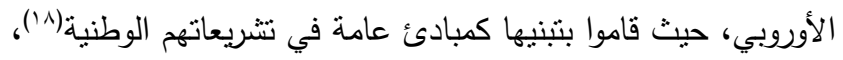

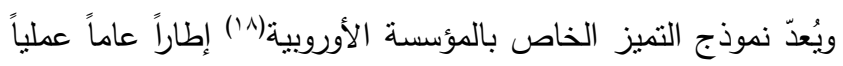
وغير توصيفي لتمكين المنظمات من:
وأصحاب المصالح. أما (Pinar \& Girad)(ro) فُعرَّفانه بأنه استثمار المنظمات الفرص الحاسمة من خلال اتباع التخطيط الاستراتيجي الفعال والالنزام لإدراك رؤية مشتركة يسودها وضوح الهدف وكفاية المصادر والحرص على الأداء. أما السلمي(؟) فيرى أن مفهوم التمبز على مستوى المنظمة يركز على بُعدين رئيسين في الإدارة الحديثة هما: البعد الأول: إنجاز نتائج غير الإدان مسبوقة للإدارة تنفوق بها: على منافسيها و تتفوق بها على نفسها بمنطق التعلم. البعد الثاني: أن كل ما بصدر عن الإدارة من أعمال

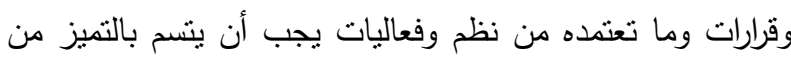

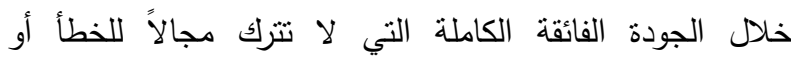

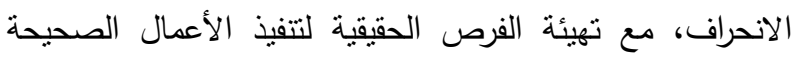

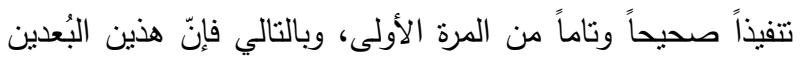

$$
\text { متكاملان لا يتحقق أحدهما دون الآخر . }
$$

ويرى الباحثان أنّ مفهوم التمبز على مستوى المنظمة هو الاخر

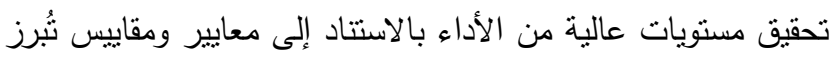

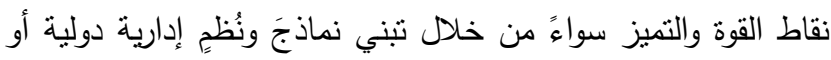
من خلال مبادرات شخصية أو مؤسسية وإجراء مقارنات مستمرة بينهما على المستوى المحلي والدولي.

\section{إدارة التميز المؤسسي:}

إن إدارة التميز هي محصلة لتطبيق مجموعة من المعايير التي

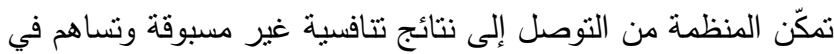
زيادة الحصة السوقية والقوة التتافسية للمنظمة (؟). كما أنها الأنشطة الني تجعل المنظمة متميزة ومتفوقة في أدائها

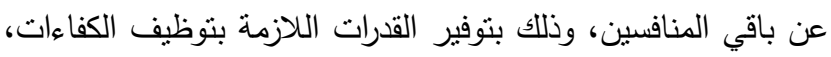
المهارات، القدرات والموارد المتاحة نوظيفاً فعالاً ومتميزاً، بشكل يجعلها متفوقة ومتقردة، وينعكس ذلك على كيفية التعامل مع العميل، سواءً الداخلي والخارجي، وكيفية أداء أنشطتها وعملياتها، وكيفية تصميم وإعداد سياساتها واستراتيجياتها الإدارية والتنظيمية وخططها التتفيذية، واهية من أجل تحقيق الأهداف المرسومة تلبية لاحتباجات كافة الأطراف

التي لها علاقة بالمنظمة، وتحقيق ما يفوق منطلباتها ونوقعاتها (r).

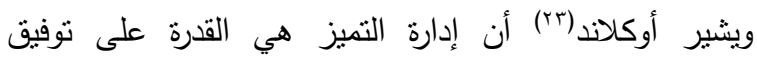
وتتسيق كافة مكونات وعناصر المنظمة، وتتغيلها في تكامل وترابط لتحقيق أعلى معدلات الفاعلية، والوصول إلى مسنوى مخرجات منميز، يُرضي كل الأطراف في المنظمة. ويلخص الباحثان أن مفهوم إدارة التميز هو اطار ومنهج فكري تتنهجه المنظمة للسعي إلى تحقيق مستويات عالية في الأداء، بما

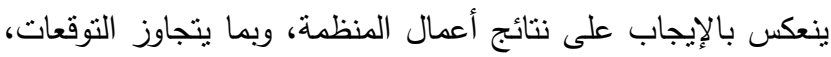


شهادة ملتزمون بالتميز (C2E) تقييم المؤسسة على مستوبين هما: C2E نجمة في حال كانت نتيجة التقييم

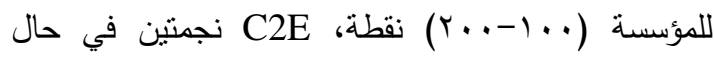
كانت نتيجة التقييم للمؤسسة ( . . . . . . . نقطة. شهادة معروفون بالتميز (R4E) تقييم المؤسسة وعلى ثلاثة مستويات هي: R4E ثلاث نجوم في حال كانت نتيجة التقييم للمؤسسة ( . . .-. . ع) نقطة، R4E أربع نجوم في

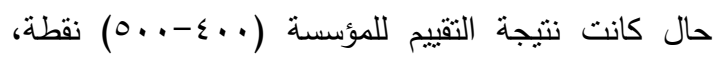
خمس نجوم في حال كانت نتيجة التقييم للمؤسسة

$$
\text { (7. . . . . . ( ) نقطة. }
$$

جائزة تميز المؤسسة الأوروبية لإدارة الجودة (EEA) وتعتبر هي أعلى مستويات التميز حسب نموذج EFQM، حيث تضم الجائزة فريقاً من المقيمين المستقلين الذين يقضون حوالي ..0 ساعة في مراجعة الوثائق وإجراء المقابلات في الموقع لكل شركة مرشحة، وتُعد طريق التقييم واحدة من بين أقوى الطرق بين كل الجوائز (r؟r).

العمليات الإجرائية لتطبيق نموذج EFQM في الجهاز المركزي للإحصاء القلسطيني:

قرر الجهاز المركزي للإحصاء الفلسطيني تطبيق نموذج EFQM ومن أجل تحقيق ذلك فقد شكل فريق عمل للقيام بهذا التطبيق من خلال خطة عمل لإعداد التقييم الذاتي من أجل تحديد فرص التحسين وما يمكن للتطبيق أن يعترض من معوقات، ونم التعاقد مع خبير دولي معتمد لدى مؤسسة EFQM للتطبيق. وتم الاستتاد على روية الجهاز بضرورة دعم المهارات والخبرات بموضوع نموذج التميز للمؤسسة الأوروبية لإدارة الجودة، ولتحقيق ذلك تم تتفيذ عدة دورات تدريبية متخصصة ومعتمدة من قبل مؤسسة EFQM للفريق ومجموعة من أصحاب القرار، وذلك في إطار نشر ثقافة التميز والإبداع في الجهاز · وتم تخطيط وتتفيذ تقييم مؤسسي شامل للجهاز وفق نموذج التمبز الأوروبي والذي استمر لمدة ب أسابيع نم من خلاله تنفيذ العديد من الزيارات الميدانية والاطلاع على الوثائق والأدلة، وانتهى هذا الجزء بتقديم تقرير تفصيلي مهني يبين كافة مجالات القوة وفرص التحسين الممكنة التي يمكن أن تفتح مجالات جديدة للجهاز لتحقيق مزيد من التميز (•). تم تتفيذ التقييم الذاتي في الجهاز من خلال استخدام أسلوب المجموعات البؤرية، ومن خلال الاطلاع على كافة وثائق ومخرجات الجهاز • وتم إعداد ثقرير التقييم الذاتي النهائي والذي يحدد في مجمل نتائجه نقاط القوة وفرص التحسين لكل معيار من معايير نموذج EFQM
تقييم وضعها خلال مسيرة التميز، بمساعدتها لفهم نقاط القوة الرئيسية لديها والفجوات المحتملة، من رؤيتها ورسالتها المعلنة.

تقديم لغة مشتركة ونمط تقكير حول المنظمة لتبادل الأفكار بفاعلية داخل المنظمة وخارجها. دمج وتتكامل المبادرات القائمة والمخطط لها، إزاء الازدواجية وتحديد الفجوات. • وضع هيكل أساسي لنظام إدارة المنظمة.

:EFQM معايير نموذج

يتكون نموذج التميز الأوروبي من تسعة معايير رئيسة، خمسةٌ منها تعتبر ممكنات، أما الأربعة الأخرى فتعتبر نتائج، ويتفرع من هذه من المعايير بr معياراً فرعياً (ع r معياراً فرعياً للممكنات، $\wedge$ معايير فرعية للنتائج)، ويندرج تحت كل معيار فرعي مجموعة من الأنشطة.

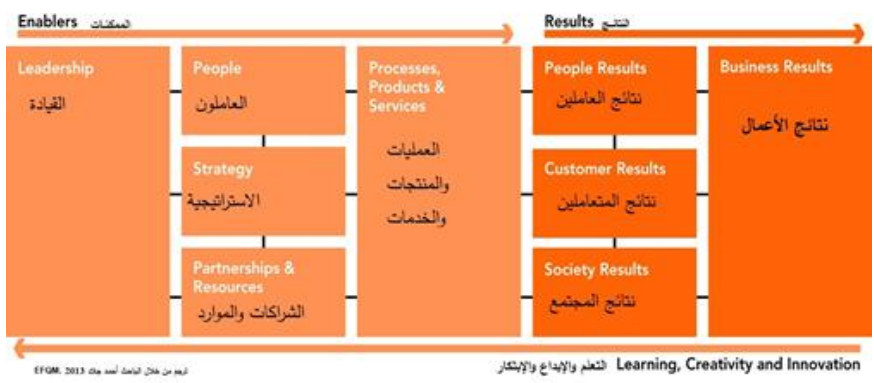

الثكل رقم (1): معايير نموذج التميز للمؤسسة الأوروبية لإدارة الجودة(1').

\section{مكنات نموذج EFQM}

I. معيار القيادة (Leadership). r. معيار الاستراتيجية (Strategy).

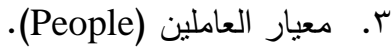

ع. معيار الشراكات والموارد (Partnership \& Resources). ๑. معيار العمليات والمنتجات والخدمات (Processes).

\section{EFQM تنائجج نموذج}

7. معيار نتائج المتعاملين (Customers Results). V . معيار نتائج العاملين (People Results). A. معيار نتائج المجتمع (Society Results). 9. معيار نتائج الأعمال (Business Results).

مستويات التميز حسب نموذج EFQM ونتائج التقييم(9'): • شهادة ملتزمون بالتميز (C2E) نجمة تقييم مشروع، ويتم الحصول عليها من خلال تتفيذ المشاريع التحسينية المنبثقة عن التقييم الذاتي وفق نموذج EFQM، ونجاح ثلاثة مشاريع منها على الأقل بعد تقييمها من قبل مؤسسة .EFQM 
الماضية، وأوصت الدراسة أيضاً بضرورة العمل على إنشاء نموذج للجودة والتميز في القطاع الحكومي من خلال تضافر جهود ديوان الرقابة المالية مع الجهاز المركزي للتقييس والسيطرة النوعية والأساتذة الجامعيين ذوي الاختصاص للعمل على تطوير مقاييس للأداء المتميز بدلاً من نظم الأداء الموجودة حالياً والتي تفتقر للثمولية في التقييم. كما قدم حيدر والسوداني(9) دراسة هدفت إلى تقييم أداء و نتائج العاملين وفق نموذج التميّز للمؤسسة الأوروبية لإدارة الجودة في مكتب المفنش العام/ وزارة الصحة، وذلك لانتهاج أساليب إدارية حديثة ومتطورة في تقييم الأداء ولعلاقة أداء المكتب بحياة المواطن. استخدمت الدراسة منهج دراسة الحالة، من خلال قائمة الفحص لجمع البيانات لأجل التقييم فضلا عن المقابلات الثخصية، وقد نم تحليل الإجابات باستخدام النسب المئوية والوسط الحسابي، والإشارة إلى نقاط القوة لغرض التعزيز، ونقاط الضعف لغرض التصحيح والتقويم، وفرص التحسين لاستثمارها وعدم تفويتها. وخرجت نتائج التقييم بنتائج جيدة، حيث حقق معيار العاملون VY نقطة من أصل نقطة ... مخصصة لهذا المعيار ضمن مجموعة الممكنات، بينما حقق معيار

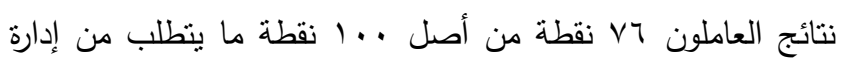
المكتب النظر في تعزيز نقاط القوة لزيادة نسب معايير الممكنات لتحقيق نتائج مميّزة، والتزكيز على نتائج التقييم المتوسطة ودراسة أسبابها ومعالجتها وإيجاد الحلول الملائمة لها. وأوصت الدراستة بضرورة الاستفادة من نتائج ثقييم أداء العاملين عند تحديد البرامج التدريبية اللازمة لتطوير وتحسين أدائهم، والاهنمام بإجراء دراسات

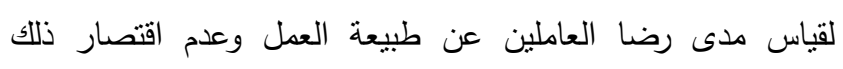
بالاعتماد على صندوق الثكاوي فقط. وقدم جرار('') دراسة هدفت إلى دراسة العلاقة بين مقومات (ممكنّات) التميز بالأداء ونتائجه في قطاع الصناعات الدوائية الفلسطيني وفق المعايير المعتمدة في نموذج التميز الأوروبي. وتم استخدام المنهج الوصفي التحليلي، وتمثل مجنمع الدراسة في قطاع الصناعات الدوائية الفلسطيني والمتمثل بثلاث شركات دوائية، وتمنلت عينة الدراسة بالمدراء الاستراتيجيين (أعضاء مجلس الإدارة، المدراء

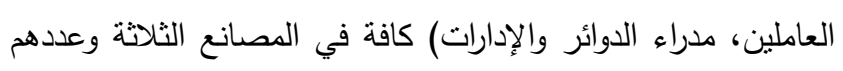

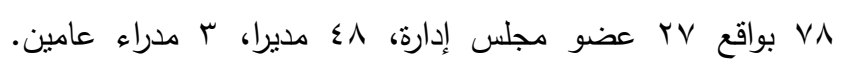
ولتحقيق هدف الدراسة تم إعداد استبانه أثشتقت منغيراتها بعد مراجعة معمقة للأدبيات ذات العلاقة. ونم توزيع الاستبانة على المدراء الإستراتيجيين كافة في مصانع الأدوية الفلسطينية وعددهم VA، ثمانع استعادة 67 استبانه صالحة للتحليل الإحصائي. وقد نم استخدام

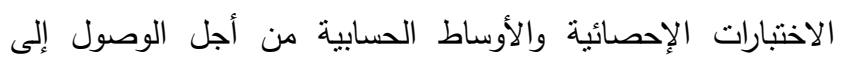
النتائج المطلوبة. أظهرت الدراسة نتيجة رئيسة مفادها وجود علاقة ذات دلالة إحصائية بين ممكنات نموذج EFQM مجتمعة ومنفصلة
واستكمل الجهاز خلال العام IV IV منطلبات الحصول على شهادة ملتزمون بالتميز (C2E) من مؤسسة EFQM، حيث تم إنجاز

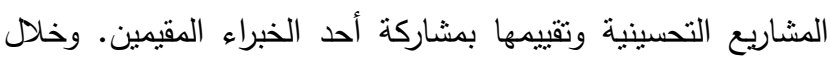
الربع الأول من العام IV . Y. تم تتفيذ مجموعة من التقبيمات التجريبية الداخلية الأخرى بهدف ضمان الجاهزية والاستعداد الكامل لتتفيذ التقييم النهائي لاستحقاق الحصول على شهادة التميز. ثم تتفيذ التقييم النهائي من قبل مُقيّم دولي معتمد من مؤسسة

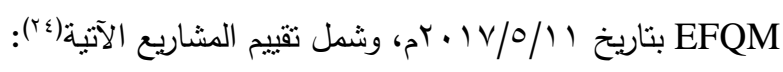
ا. مشروع مؤشرات الأداء الخاصة بمؤشرات الاستراتيجية

$$
\text { وتحقيق أهداف الجودة. }
$$

r. مشروع حوسبة الإجراءات الإدارية.

r. مشروع النموذج المعياري لتخطيط وتتفيذ مشروع إحصائي

.(GSBPM)

وبناءً على نتائج هذا التقييم فقد تم منح الجهاز شهادة ملتزمون

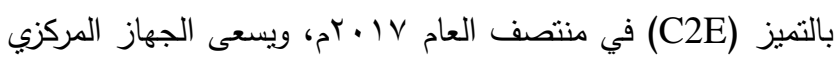
للإحصاء الفلسطيني دائما إلى تحقيق الاستدامة في التميز، وتحقيق روئية الجهاز ورسالته في إنتاج الإحصاءات الرسمية ونشرها بجودة

$$
\text { عالية وبأفضل الممارسات الإحصائية(؛) (1). }
$$

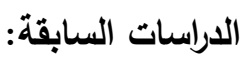

قام عبد الوهاب وسليمان(') بإعداد دراسة هدفت إلى تسليط الضوء على إمكانية تطبيق نموذج التمبز الأوروبي EFQM في تقييم أداء مستشفى النعمان العام، من خلال قوائم الفحص (Checklists)

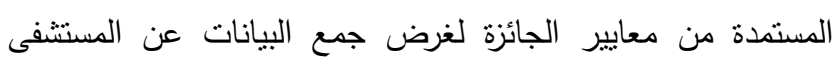
وتقييمها، ونم اعتماد منهجية نموذج EFQM في تقييم المسنشفى بشكل كامل، وتم اعتماد معاييره كأداة للاراسة وتم استخدام المقابلة الثخصية والسجلات الرسمية للمسنشفى كأساليب لجمع البيانات للاراسة، ونم تحليل النتائج وفق منطق رادار • وأثنتت النتائج أن هناك ضماناً للجودة وبداية للتحسين المستمر فيها. وكان من أهم الاستتناجات أن أعلى تطبيق وتوثيق حققه المستشفى هو لمعيار

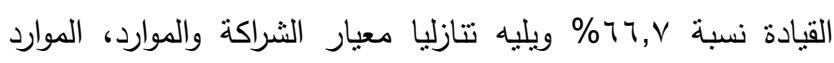
البشرية، العمليات، والسياسة والاستراتيجية للممكنات، أما النتائج فكانت نتائج ضعيفة والتي تراوحت بين نسبة م, • r\% م لمعياري نتائج

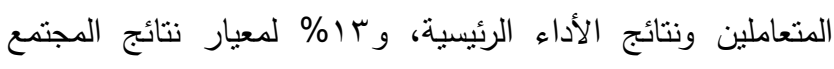
و 9,0\% لمعيار نتائج الموارد البشرية. وأوصت الدراسة بتعزيز إدارة المستشفى لنقاط القوة لزيادة نسب معايير الممكنات التي حققت نتائج مرضية، والحد من نتائج التقييم الضعيفة ودراسة أسبابها ومعالجتها وإيجاد الحلول الملائمة لها، واعتماد معادلات أو نسب مئوية لقياس الأداء للتعرف على التحسن أو التراجع في الأداء مقارنة بالفترات 
الاختلاف =r r ع على التوالي، من بينها نم تلقي معيار الناس أعلى

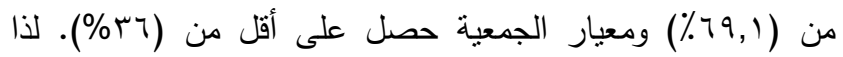
أظهرت النتائج أن جميع الفرضيات البحثية قد نم قبولها وكانت هنات الته

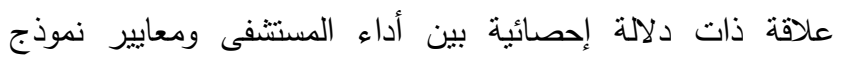

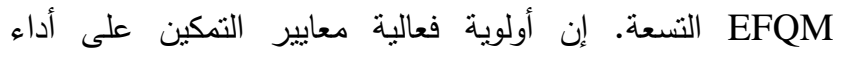
المستشفى جاءت كما يلي: معايير العمليات والثركاء والموارد والقيادة والناس والسياسات والاستراتيجيات، ومعايير الاختلاف تنثمل: نتائج

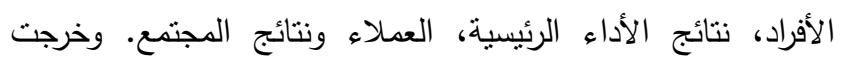

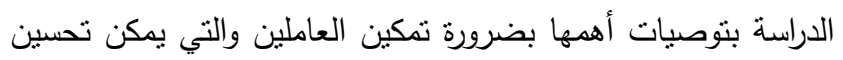

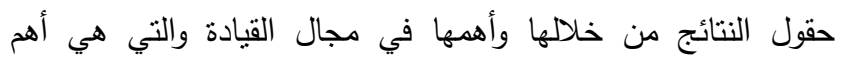

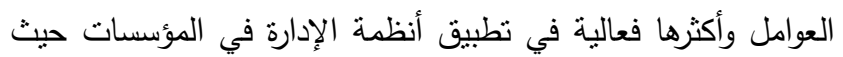

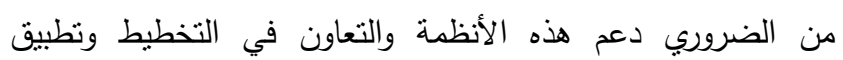

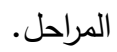

وللتركيز على عناصر التمكين في نموذج EFQM فقد قدم

Bou-Llusar

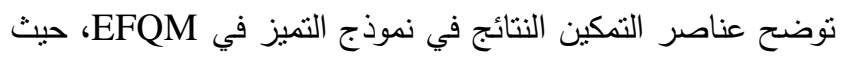
تم إلقاء نظرة متعمقة على نموذج EFQM من خلاحل تقييم كيفية ترابط معايير التمكين والنتائج، وكيف تؤثر العوامل التمكينية ككل

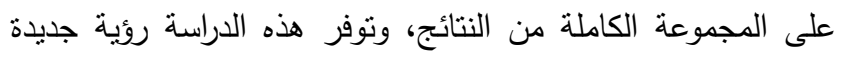
وفهم لجميع معايير EFQM. نم استخدام تحليل الارتباط الكنسي

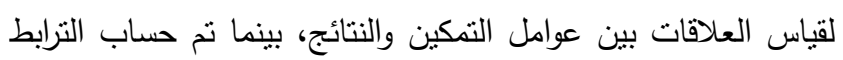
ضمن مجموعات المتغيرات هذه لاختبار العلاقة السبيية المقترحة، ونم استخدام بيانات من استيان نم إجراؤه على بـ؛ شركة (قطاعي

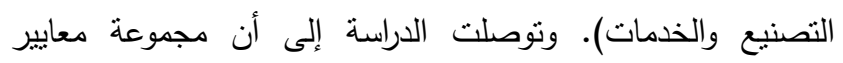

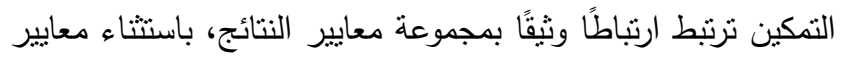

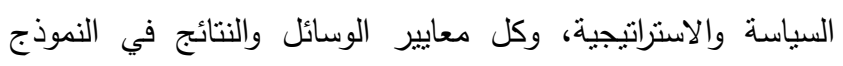
الأوروبي تقوم بمساهمة مهمة في هذه العلاقة بنفس الطريقة، ويساهم كل معيار من الوسائل في كسب النتائج.

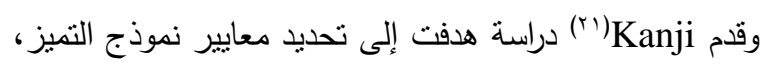

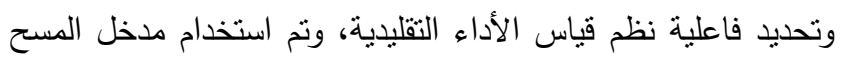

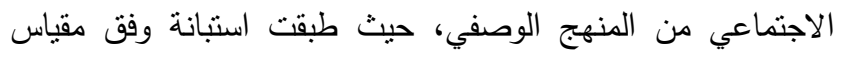

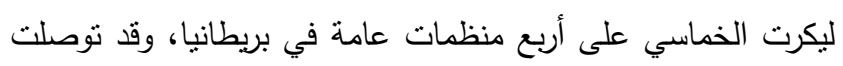

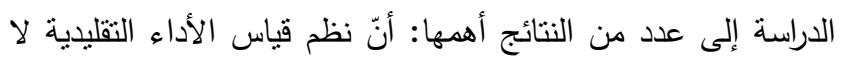

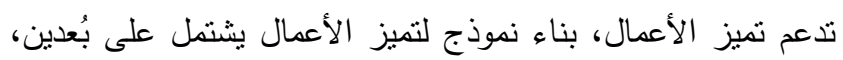

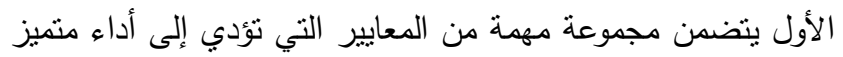
للمنظمة، إذا تم التركيز عليها وإدارتها بشكل فاعل وهي: القيادة التهادي بصفتها العنصر الدحرك الرئيسي ورضا العاملين، والإدارة بالحقائق،

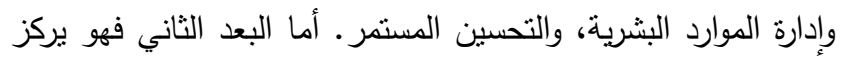

وبين نتائج الأداء مجتمعة ومنفصلة ممثلة برضا العاملين والزبائن والمجتمع وبزيادة الأرباح الصافية والمبيعات والحصة السوقية

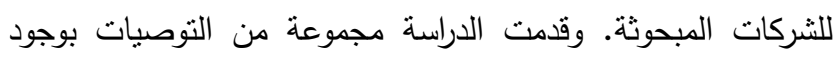

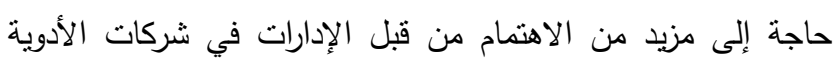

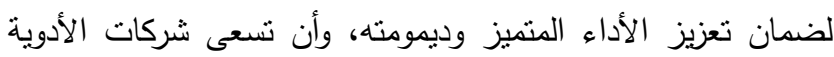

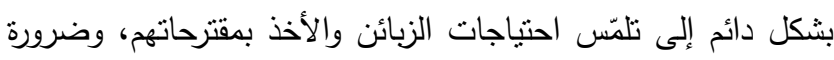

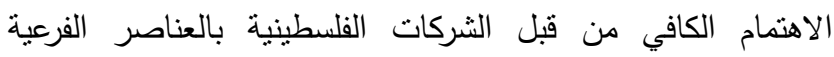

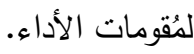

أما دراسة بعقوب('1) فقد هدفت إلى معرفة إلى أي مدى يمكن

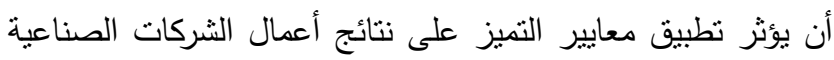

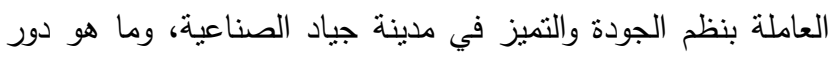
أخلاقيات الأعمال كتغير وسيط في ذلك. وقد نم استخدام المنهج الوصفي، حيث تمثل مجتمع الدراسة بالموظفين العاملين في مدينة جياد الصناعية، وبلغت عينة الدراسة . .1 موظف، وتم استخدام

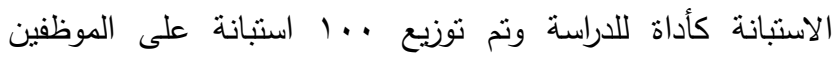

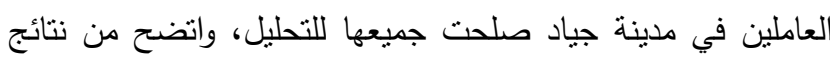

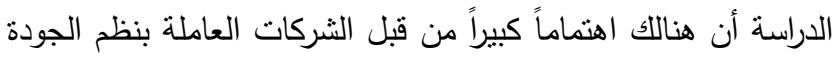

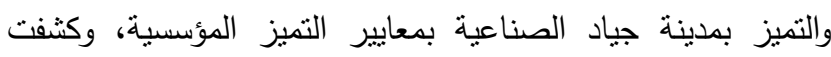
نتائج التحليل عن أن نولي القيادة لمسألة ومراجعة وتحسين الأداء

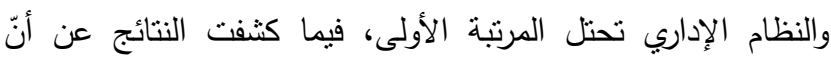

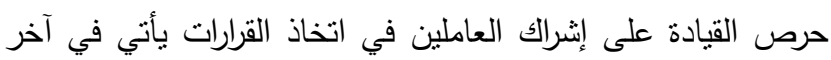

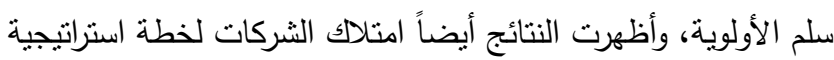

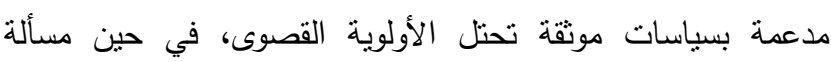

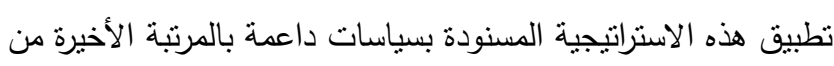

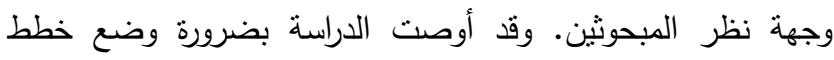
استراتيجية طويلة الددى لكل المراكز على مستوى الإدارات والأقسام والوظائف، توضيح وشرح رسالة وأهداف الثركة للعاملين، وإنشرالك الثيل

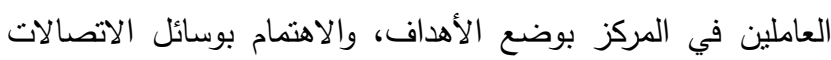

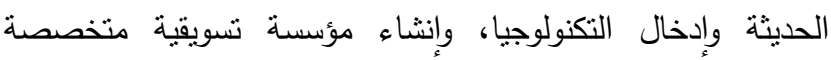

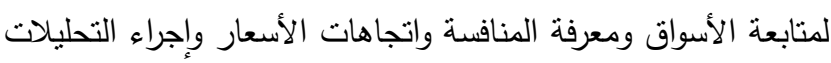

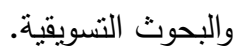
وأجرى Gorji و Siami(·) دراسة هدفت إلى إجراء تقييم ذاتي حسب نموذج EFQM في المستشفى، ومن ثم تحديد العلاقة بين

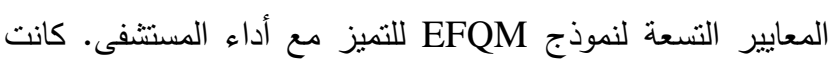

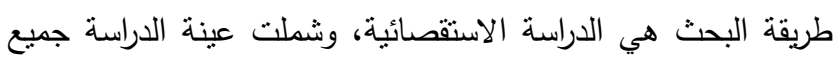

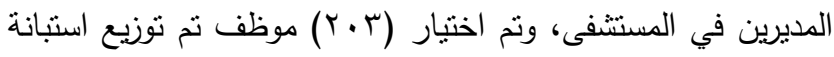
الدراسة عليهم، وتم استخدام منطق الرادار لتحليل العلاقة للأداء.

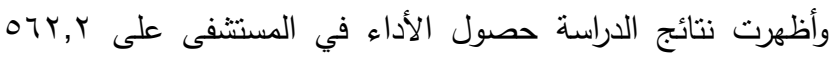

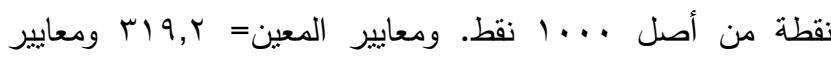


إن ما تميزت بـه هذه الاراسة هو أنه قد تم تطبيقها على منظمة

قد قامت بإجراء التقييم الذاتي من قبل مُقتيٍّ مُعتمدٍ من مؤسسة EFQM وقامت بتطبيق خطة تحسين من خلالها تم إجراء التقييم النهائي من قبل مقيّ خارجي والتي على أساسها حصل الجهاز المركزي للإحصاء الفلسطيني على شهادة ملتزمون بالتميز في ملي منتصف عام V V Y Y، وتعتبر المدة بين حصول الجهاز على الجائزة وبين تتفيذ هذه الدراسة مدة زمنية منطقية لدراسة العلاقة بين ممكنات النموذج مع النتائج التي تحققت في الجهاز، كما تميزت الدراسة بإبرازها لنقاط القوة وفرص التحسين في الجهاز المركزي للإحصاء الفلسطيني، وما تميزت الدراسة به أيضاً وبشكل قوي تطرقها إلى فرهائ محور الاستدامة في تطبيق التميز وهو ما ينادي به نموذج التميز للمؤسسة الأوروبية لإدارة الجودة ويعتبره ركيزة من ركائز التميز المؤسسي ويعذّ أحد أبرز مفاهيم النموذج الرئيسية.

\section{إجراءات الدراسة:}

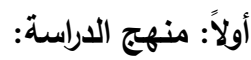

اعتمدت الدراسة على المنهج الوصفي التحليلي الذي يقوم باستخراج العلاقات بين ممكنات نموذج EFQM ونتائجه في الجهاز

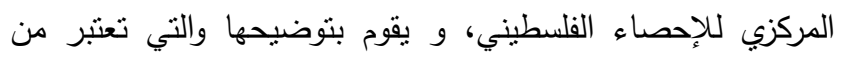

$$
\text { أنشر الأدوات المستخدمة في المنهج الوصفي. }
$$

\section{ثانياً: مجتمع وعينة الدراسة:}

يتمتل مجتمع الدراسة بالموظفين الدائمين الذين بعملون في

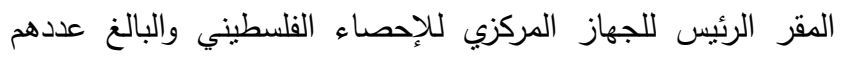

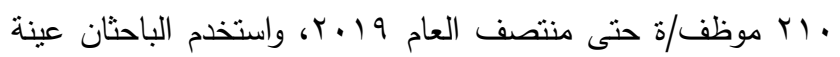

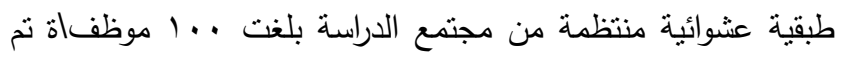

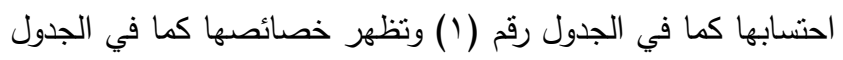

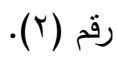

جدول رقم (1): احتساب عينة الدراسة في الجهاز.

\begin{tabular}{|c|c|c|}
\hline 210 & $\mathrm{~N}$ (population size) & حجم المجتمع \\
\hline 1.96 & z (confidence level) & اختبار التوزيع الطبيعي \\
\hline 0.07 & E (+- error) & نسبة الخطأ \\
\hline 0.5 & $\mathrm{p}$ & حتمال النجاح (انتثار الظاهرة) \\
\hline 0.5 & $q$ & متممة (P) \\
\hline 100 & $\mathrm{n}$ & حجم العينة \\
\hline
\end{tabular}

جدول رقم (ץ) : خصائص أفراد عينة الدراسة.

\begin{tabular}{|c|c|c|c|c|c|c|c|}
\hline المجموع & الخامسة & الرابعة & الثالثة & الثانية & الأولى & العليا & الفئة الوظيفية \\
\hline 09 & $r$ & $r$ & $r$ & rq & 11 & $r$ & الذكور \\
\hline \&1 & . & . & 。 & $r_{\Lambda}$ & 7 & r & الإناث \\
\hline $1 \ldots$ & $r$ & $r$ & $\wedge$ & or & $r \varepsilon$ & 0 & المجموع \\
\hline
\end{tabular}

على قيم وثقافة المنظمة بصفتها محركاً رئيسياً لتحريك العمليات وجعلها منظمة متعلمة. وتلبي احتياجات أصحاب المصالح.

\section{التعقيب على الدراسات السابقة:}

تتاولت الدراسات السابقة موضوع نموذج التميز للمؤسسة

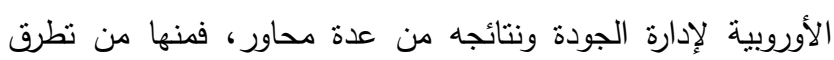

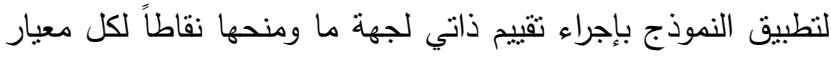
من المعايير وصولاً إلى نتيجة نهائية تبرز مكانة المنظمة في مجاء لهال

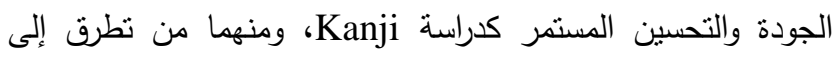
النموذج من خلال دراسة العلاقة بين ممكنات النموذج ونتائجه كدراسة ولنة عبد الوهاب وسليمان ودراسة Gorji و Siami. ومنهم من تطرق إلى دئى

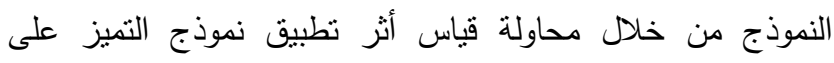

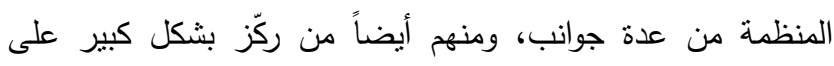

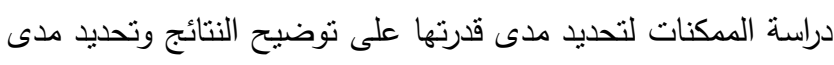
فاعلية نظم قياس الأداء التقليدية.

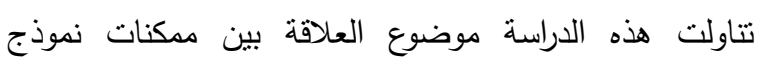
EFQM تقارب موضوع هذه الدراسة بشكل مباشر مع دراسة جرار ودراسة لجنة و Gou-Llusar ودراسة Gouri الدراسات السابقة العلاقة بين المككنات والنتائج من حيث واتئ وجودها، وبشكل عام فإن بعض هذه الدراسات قامت بدراسة العلاقة بين

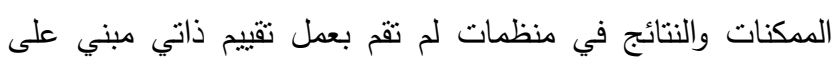

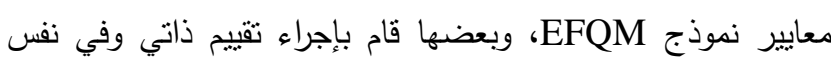

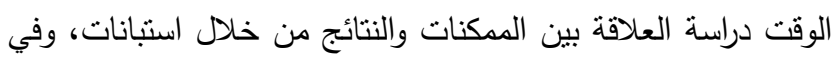
حقيقة الأمر فإن التقييم الذاتي وفق نموذج التميز للمؤسسة الأوروبية

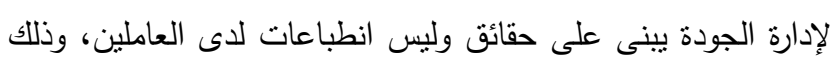

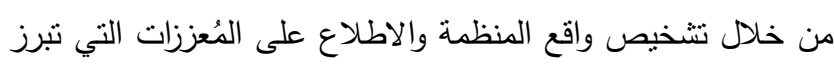

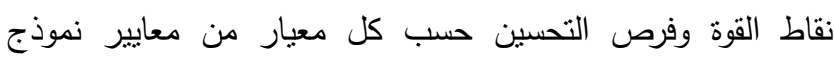

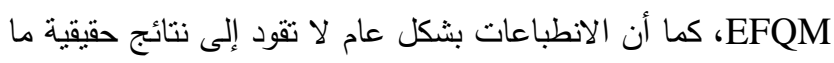

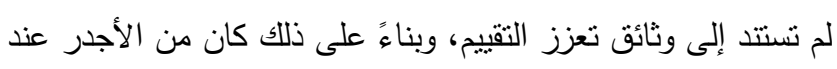

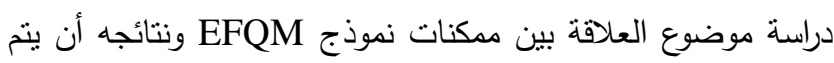

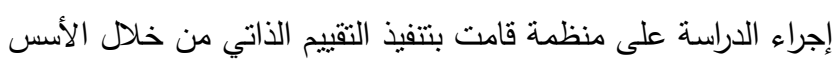

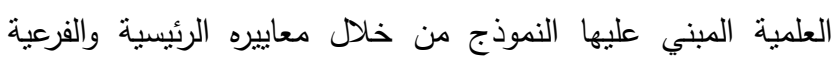

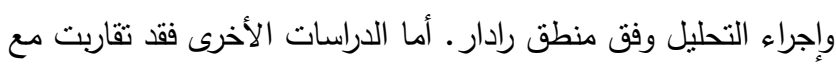
الدراسة الحالية من حيث تقييم ممكنات النموذج والنتائج في الجهاز من خلال انطباعات العاملين في الجهاز ، وهذه الدراسات هي كالآتي:

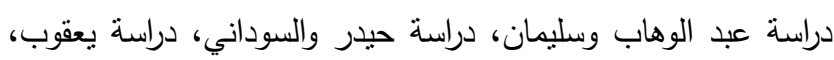

دراسة Kanji. 


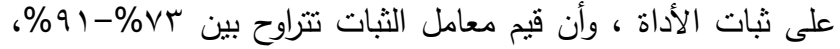
وهذه القيم مقبولة وتدل على ثبات أداة الدراسة.

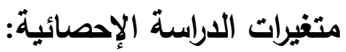

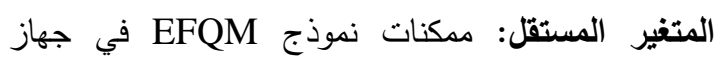
الإحصاء، وتثمل: (القيادة، الاستراتيجية، العاملون، الثراكات

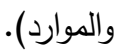

المتغير التابع: نتائج نموذج EFQM مجتمعة في جهاز

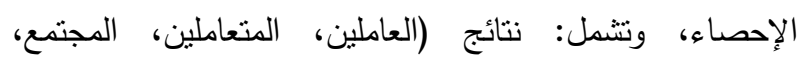

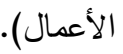

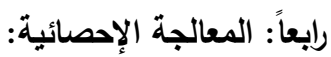

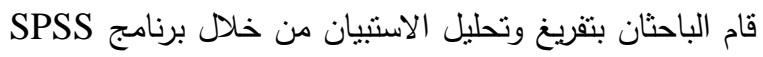
الإحصائي واختبار ANOVA، وتم استخراج المتوسطات الحسابية والانحرافات المعيارية والنسب المئوية لكل فقرة من فقرات الاستبانة وكذلك على المجال الكلي لأسئلة الدراسة، وتم عمل مقارنات بين المتغير الثابع والمتغيرات المستقلة المكونة من ثلاثة خيارات وأكثر.

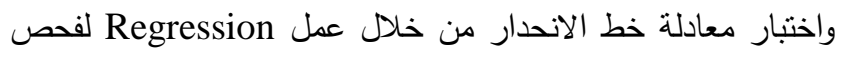
العلاقة. وتم عمل ارتباط ثنائي بين كل المككنات والننائج من خلال

.(Pearson correlation) وللحكم على تقدير المتوسطات الحسابية، تم استخدام المعايير

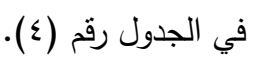

جدول رقم (؛) ): معيار الحكم على تقدير المتوسطات الحسابية.

\begin{tabular}{|c|c|c|}
\hline الارجة & المستوى & الرقم \\
\hline منخفضة جداً & 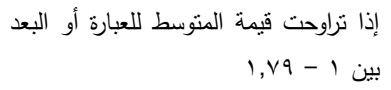 & 1 \\
\hline منخفضة & 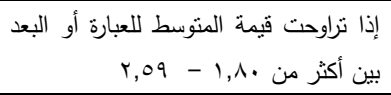 & r \\
\hline متوسطة & 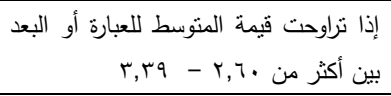 & $r$ \\
\hline مرتفعة & 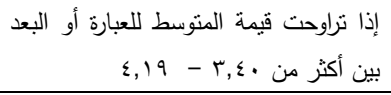 & $\varepsilon$ \\
\hline مرتفعة جداً & 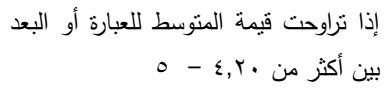 & 0 \\
\hline
\end{tabular}

\section{نتائج الدراسة ومناقشتها:}

النتائج المتعلقة بالسؤال الأول: ما مدى توافر مدكنات نموذج

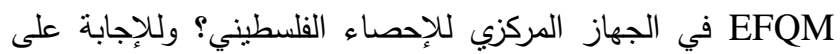

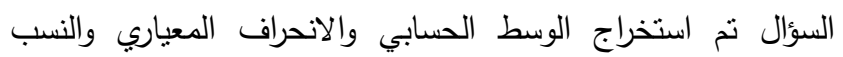
المئوية لكل محور من الممكنات كما في الجدول رقم (0).

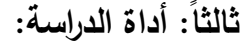
نم استخدام الاستبانة كأداة لجمع البيانات والمعلومات للدراسة والتي اشتملت على قسمين:

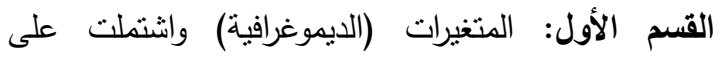
معلومات حول (الجنس والفئة الوظيفية ومجال العمل وسنوات

$$
\text { الخبرة ) في الجهاز . }
$$

القسم الثاني: اثتمل على فقرات الاستبانة المؤلفة من

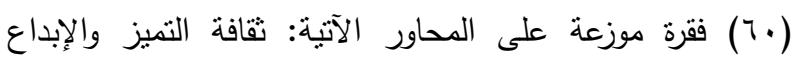

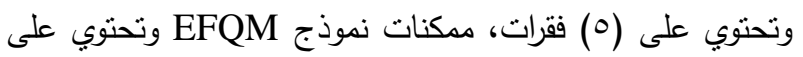
(TV) فقرة، نتائج نموذج EFQM ويحتوي على (Tr) فقرة)

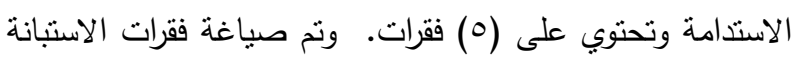
من خلال وضع مجموعة من الفقرات الخاصة بقياس ثقافة التميز

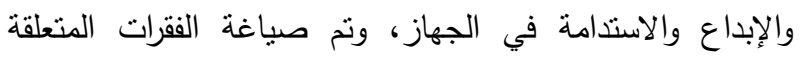

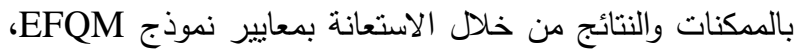
وذلك بما يتلاءم مع طبيعة عمل الجهاز وينسجم مع مخرجاته للحصول على نتائج معيارية مبنية على أسس وعناصر معل معتمدة في التقييم المؤسسي.

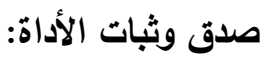

تم التأكد من صدق وثبات فقرات الاستبيان من خلال الصدق

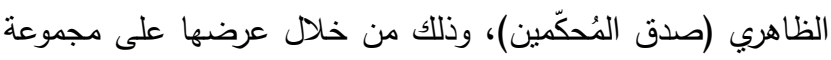

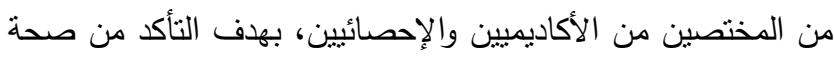

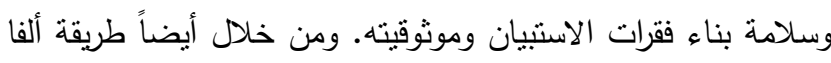
كرونباخ (Cronbach's alpha) حيث قام الباحثان بإجراء اختبار ألفا كرونباخ لمعرفة ثبات فقرات الاستيان، وتم استخراج قيمة معامل

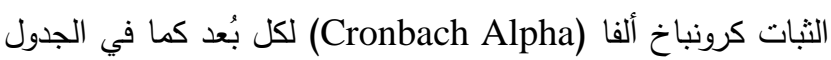
رقم (r)، ويقيس هذا المعامل الاتساق الداخلي في فقرات الاسنبانة.

\begin{tabular}{|c|c|c|}
\hline كرونباخ ألفا & عدد الفقرات & المحور \\
\hline$\% \vee r$ & ○ & ثقافة التميز \\
\hline$\% \wedge 9$ & 7 & القيادة \\
\hline$\% \wedge 4$ & 0 & الاستراتيجية \\
\hline$\% \wedge 0$ & 7 & الموظفون \\
\hline$\% \wedge 1$ & 0 & الشراكات والموارد \\
\hline$\% \wedge r$ & 0 & العمليات \\
\hline$\% 91$ & rt & النتائج \\
\hline$\% 91$ & 0 & الاستدامة \\
\hline$\% 97$ & 7. & معامل الثبات الإجمالي \\
\hline
\end{tabular}
جدول رقم (ץ): معامل ثبات Cronbach Alpha) لمحاور الاستيبان.

من خلال الجدول رقم (r) نلاحظ أن قيمة معامل الثبات

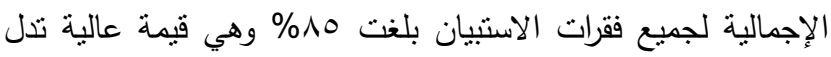


بالنظام الإداري بشكل قوي، حيث أبدت جميع الفقرات التي تمحورت

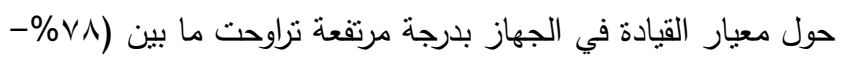

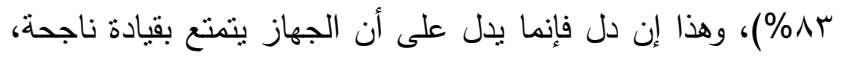

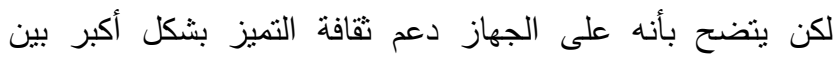
الموظفين والحرص على ضمان المرونة في العمل.

جدول (V): دور الاستراتيجية كأحد ممكنات نموذج EFQM في الجهاز.

\begin{tabular}{|c|c|c|c|c|}
\hline المئوية & الانحراف & المتوسط الحسبي & الفقرات & الرقم \\
\hline $82 \%$ & .530 & 4.11 & فيتم صياغة الاستراتيجية بناءُ على احتيات وتوقات المستخمين. & 1 \\
\hline $83 \%$ & .551 & 4.14 & 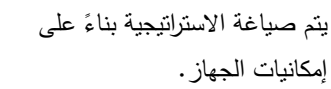 & 2 \\
\hline $80 \%$ & .577 & 3.99 & 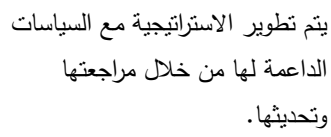 & 3 \\
\hline $80 \%$ & .512 & 4.00 & 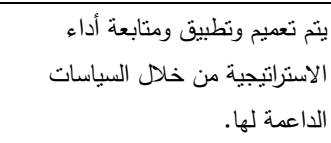 & 4 \\
\hline $78 \%$ & .584 & 3.89 & 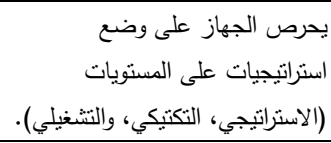 & 5 \\
\hline $81 \%$ & .550 & 4.02 & الدرجة الكلبة & \\
\hline
\end{tabular}

يظهر الجدول رقم (V) أن الدرجة الكلية لدور الاستراتيجية كمكن من ممكنات نموذج EFQM وتأثيرها في النتائج في الجهاز

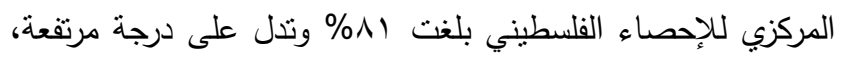

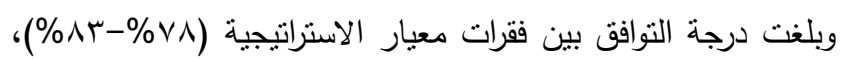

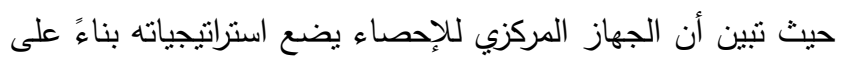

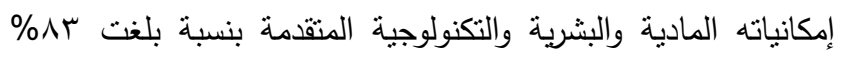
وهي نسبة عالية، وأن نسبة التوافق هذه ندل على أن الجهاز لدية لديه

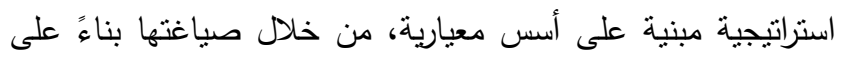

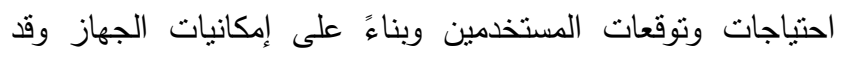

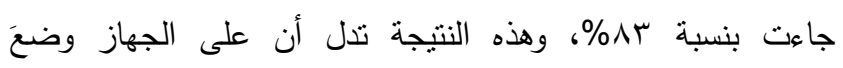
استراتجيات أقوى على المستويات التكتيكية والتشغيلية كي تدعم الخطة

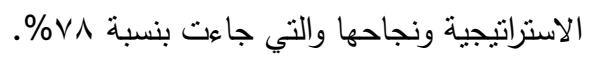

جدول (^): دور الموظفين كأحد ممكنات نموذج EFQM في الجهاز.

\begin{tabular}{|c|c|c|c|c|}
\hline النسبية & الانحراف & المستوسط & الفقرات & الرقم \\
\hline $82 \%$ & .825 & 4.08 & للجهارك الموظفون في إعداد الخطط السنوية & 1 \\
\hline $82 \%$ & .541 & 4.10 & 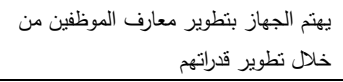 & 2 \\
\hline $70 \%$ & .904 & 3.52 & 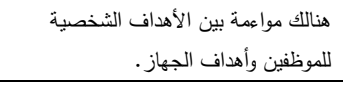 & 3 \\
\hline $75 \%$ & .767 & 3.76 & بين إمكانياتهم من خلالكين للموظفين من إطلاق كامل & 4 \\
\hline
\end{tabular}

جدول (0): معايير وممكنات نموذج EFQM في الجهاز.

\begin{tabular}{|c|c|c|c|c|}
\hline التوافق على الاجابة & الخطأ & الانحراف & الكسابي & المعيار \\
\hline $83 \%$ & 0.0445 & 0.44554 & 4.174 & العطليات \\
\hline $81 \%$ & 0.0439 & 0.43915 & 4.026 & الاستراتيجية \\
\hline $80 \%$ & 0.0395 & 0.39530 & 4.010 & الشراكات والموارد \\
\hline $78 \%$ & 0.0535 & 0.53538 & 3.896 & القيادة \\
\hline $78 \%$ & 0.0583 & 0.58299 & 3.895 & الموظفين \\
\hline $80 \%$ & 0.0469 & 0.47900 & 4.000 & الدرجة الكلية \\
\hline
\end{tabular}

يتبين من النتائج الواردة في الجدول رقم (ه) أنّ الدرجة الكلية

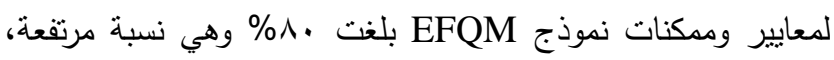
وتدلُ على أن هذه المكنات قوية في الجهاز، حيث دور العمليات والمنتجات جاء بنسبة س^^\%، في حين جاءت الاستراتيجية بنسبة

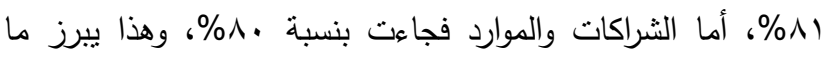
يتمتع به الجهاز المركزي للإحصاء الفلسطيني من قوة في العمليات

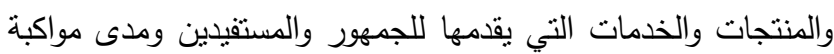
الجهاز للتطورات السريعة في المجالات التقنية والتكنولوجية، وكذللك

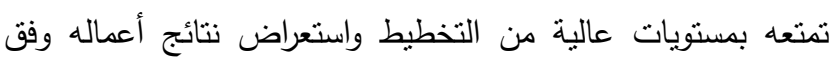

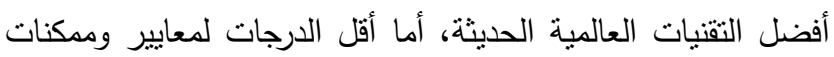
نموذج EFQM فجاء معيار القيادة والموظفين بنفس النسبة والتي بلغت \%>\% وهي نسبة مُرضية ولكن هنالك مجال للسعي لتحسينها للحصول على نقاط أعلى في مستوى الأداء المؤسسي.

جدول (†): دور القيادة كأحد ممكنات نموذج EFQM في الجهاز.

\begin{tabular}{|c|c|c|c|c|}
\hline النسئة & المعياري & الحستوسط & الفقرات & الرقم \\
\hline $80 \%$ & .628 & 4.01 & والأهداف الرئيسية للجهاز . الرؤية والرسالة والقيم & 1 \\
\hline $80 \%$ & .559 & 3.99 & وتوبوم القادة بتحديد ومتابعة ومراجعة & 2 \\
\hline $79 \%$ & .649 & 3.94 & خلال فهم احتياجاتهم. & 3 \\
\hline $77 \%$ & .677 & 3.84 & وتؤوجيه التحسينات الخاصة بتديد ومتابعة ومراجعة & 4 \\
\hline $76 \%$ & .773 & 3.78 & 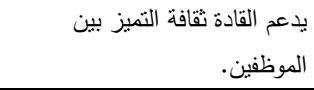 & 5 \\
\hline $76 \%$ & .672 & 3.82 & فيحرص القادة على ضمان المرونة & 6 \\
\hline $78 \%$ & .658 & 3.89 & الدرجة الكلية & \\
\hline
\end{tabular}

يتبين من الجدول رقم (؟) بأن •^\% من الموظفين موافقون

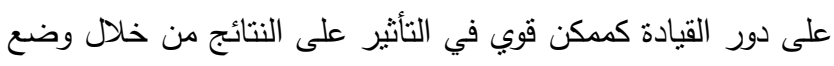

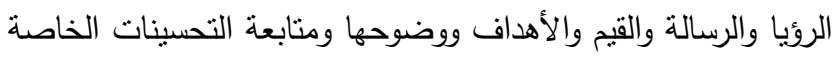


جدول (· ( ): دور العمليات كأحد ممكنات نموذج EFQM في الجهاز

\begin{tabular}{|c|c|c|c|c|}
\hline المئوية & المعياري & المستوسط & الفقرات & الرقم \\
\hline $80 \%$ & .531 & 3.98 & 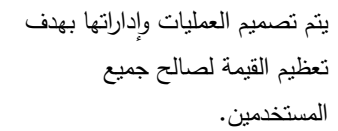 & 1 \\
\hline $86 \%$ & .686 & 4.29 & يتم ترويج مخرجات الجهاز & 2 \\
\hline $84 \%$ & .581 & 4.19 & 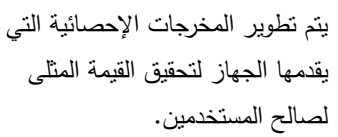 & 3 \\
\hline $84 \%$ & .537 & 4.21 & وتنتم إنتاج المخرجات الإحصائية لتلبية & 4 \\
\hline $84 \%$ & .532 & 4.20 & 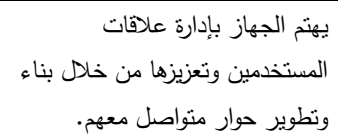 & 5 \\
\hline $83 \%$ & .625 & 4.14 & الدرجة الكلية & \\
\hline
\end{tabular}

يتبين من الجدول رقم (·) أنّ نتائج معيار وممكن دور

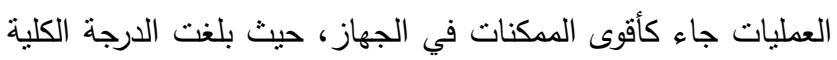
بنسبة r^\% وأن المنوسط الحسابي يتجاوز درجة النوافق إلى موافق بثدة تقريباً، والذي يعتبر أن له دوراً رئيساً في النتائج وهي نسبة النية عالية، وهذا يؤكد على أن العمليات والمخرجات الإحصائية في الجهاز تتتعع بقوة من خلال تصميمها وإداراتها وترويج مخرجاتها والتطوير

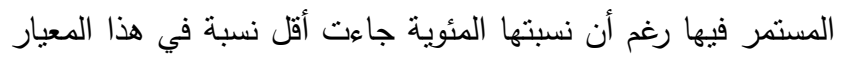
والتي بلغت ،^\%، وهذا ينعكس ايجاباً على نتائج ومخرجات الجهاز رغم الحاجة المستمرة لبلوغ نسب أفضل من خلال التحسينات المستمرة

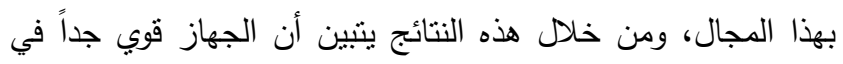

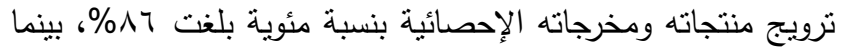
ظهر تطوير وانتاج المخرجات بنسبة قوية بلغت ع^\%، كما يتبين أن الجهاز يهنم بإدارة علاقات المستخدمين وتعزيزها من خلال بناء وتطوير حوار متواصل معهم بنسبة ع^\% أيضاً. النتائج المتعلقة بالسؤال الثاني: ما العلاقة بين ممكنات نموذج ونتائجه في الجهاز المركزي للإحصاء الفلسطيني؟ (EFQM)

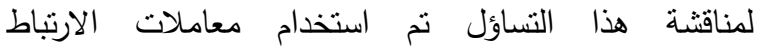
لهعرفة مدى ارتباط المكنات مع بعضها البعض لهارل (Correlation) ومع نتائج النموذج في الجهاز المركزي للإحصاء الفلسطيني. جدول (1 1): الارتباط الثنائي بين ممكنات ونتائج نموذج (EFQM) في الجهاز.

\begin{tabular}{|c|c|c|c|c|c|c|}
\hline النتائج & العمليات & والثرارد & الموظفين & الاستراتيجية & القيادة & المعيار \\
\hline $64 \%$ & $53 \%$ & $56 \%$ & $57 \%$ & $58 \%$ & $100 \%$ & القيادة \\
\hline $56 \%$ & $48 \%$ & $66 \%$ & $49 \%$ & $100 \%$ & $58 \%$ & الاستراتيجية \\
\hline
\end{tabular}

\begin{tabular}{|c|c|c|c|c|}
\hline 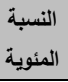 & المعياري & المتوسط & الفقرات & الرقم \\
\hline $78 \%$ & .823 & 3.90 & جيتم التواصل بين الموظفين بفاعلية في & 5 \\
\hline $80 \%$ & .718 & 4.01 & في عمليات تحفيز الموظفين وحثهم على المشاركة & 6 \\
\hline $78 \%$ & .763 & 3.89 & الدرجة الكلية & \\
\hline
\end{tabular}

يتبين من الجدول رقم (^) أن الدرجة الكلية لدور الموظفين

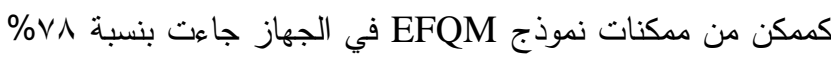
وهي نسبة ودرجة مرتفعة، ويتبين ذلك من خلال إثرالك العاملين في الجهاز في إعداد الخطط السنوية والتي جاءت بنسبة بیر\%، وأن الجهاز يهتم بنطوير معارف الموظفين من خلال نطوير قدراتهم بنسبة

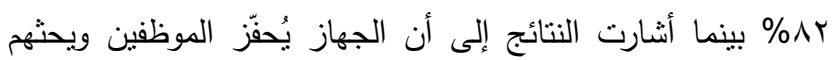

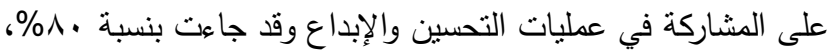
لكن على الجهاز دور كبير في الاهتمام بمواءمة الأهداف الثخصية

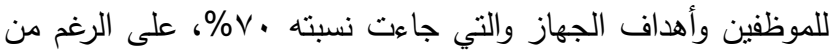
صعوبة تطويع الأهداف، لكن لا بد من بذل مجهود قوي لتحسين ذلك.

جدول (9): دور الثراكات والموارد كأحد مككنات نموذج EFQM في الجهاز.

\begin{tabular}{|c|c|c|c|c|}
\hline النسبة & الانحراف & المتوسط & الفقرات & الرقم \\
\hline $78 \%$ & .545 & 3.92 & 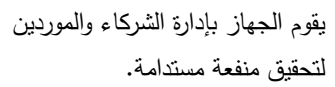 & 1 \\
\hline $82 \%$ & .477 & 4.12 & مالموام الجهاز بادارة المباني والمعدات & 2 \\
\hline $82 \%$ & .424 & 4.11 & لدوم الجهاز بإدارة التقنية والتكنولوجيا & 3 \\
\hline $79 \%$ & .577 & 3.97 & فيتم تزويد القادة في الجهاز بمعلومات & 4 \\
\hline $79 \%$ & .573 & 3.93 & قيتم إدارة المعلومات والمعرفة لبناء & 5 \\
\hline $80 \%$ & .519 & 4.01 & الدرجة الكلية & \\
\hline
\end{tabular}

يتبين من الجدول رقم (9) أنّ نتائج معيار وممكن الثراكات

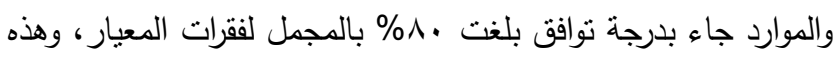

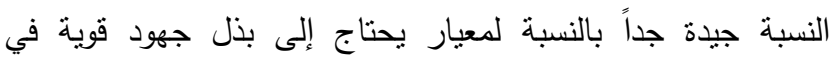

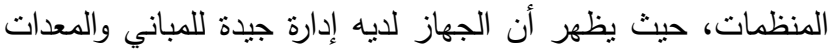

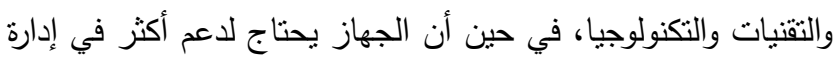
الثركاء والموردين بشكل خاص لتحقيق منفعة مستدامة. 
ولفحص العلاقة الأحادية بين كل ممكن من ممكنات نموذج EFQM

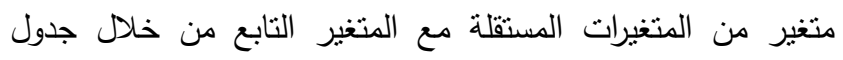

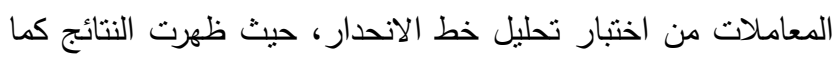

$$
\text { في الجدول الآتي: }
$$

جدول رقم (£ 1): ملذص النموذج باستخام تحليل معادلة خط الانحدار.

\begin{tabular}{|c|c|c|c|c|c|}
\hline \multirow{2}{*}{ الإحصائية } & \multirow{2}{*}{ دالة t } & \multirow{2}{*}{$\begin{array}{c}\begin{array}{c}\text { Standardized } \\
\text { Coefficients }\end{array} \\
\text { Beta }\end{array}$} & \multicolumn{2}{|c|}{$\begin{array}{l}\text { Unstandardized } \\
\text { Coefficients }\end{array}$} & \multirow{2}{*}{ النموذج } \\
\hline & & & $\begin{array}{l}\text { Std. } \\
\text { Error }\end{array}$ & B & \\
\hline .022 & 2.320 & & .230 & .533 & (الثابت) \\
\hline .008 & 2.689 & .198 & .053 & .143 & القيادة \\
\hline .958 & .053 & .004 & .067 & .004 & الاستر اتيجية \\
\hline .101 & 1.656 & .117 & .047 & .077 & الموظفين \\
\hline .003 & 3.102 & .276 & .087 & .271 & و الثر اكات \\
\hline .000 & 5.275 & .417 & .069 & .363 & العمليات \\
\hline
\end{tabular}

وتشير النتائج وفق جدول رقم (ع () إلى أن قيمة الدلالة

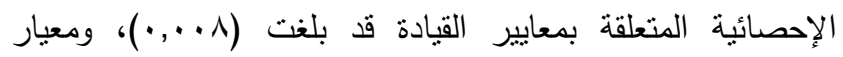

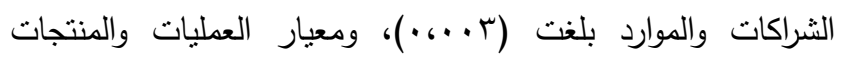

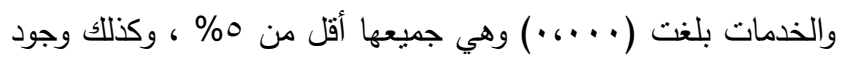

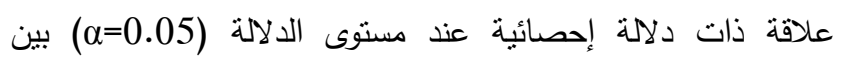

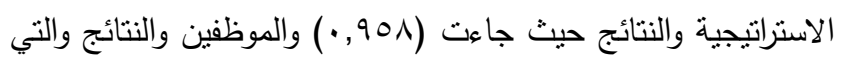

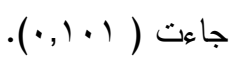

\section{النتائج المتعلقة بالسؤال الثالث: ما مستوى ثقافة التميز في}

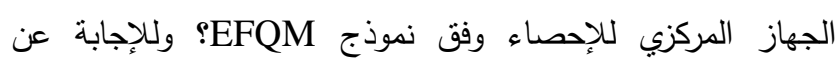

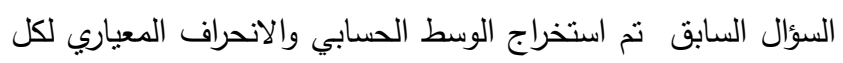

$$
\text { فقرة من فقرات محور ثقافة التميز كما في الجدول رقم (10). }
$$

\begin{tabular}{|c|c|c|c|c|}
\hline المئوية & الانحراف & الحسابي & الفقرات & 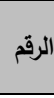 \\
\hline $76 \%$ & .609 & 3.82 & هنتاك دراية ووعي لدى الموظفين في الجهاز بمفهوم & 1 \\
\hline $79 \%$ & .547 & 3.94 & لدى الجهاز بيئة عمل تدعم وتشجع الإبداع والتميز. & 2 \\
\hline $73 \%$ & .833 & 3.65 & ألشعر بأنتي مشارك في عملية التطوير القائمة في & 3 \\
\hline $74 \%$ & .849 & 3.69 & استخدامه لنحقيق أفضل المستويات في الجهاز & 4 \\
\hline $73 \%$ & .798 & 3.64 & 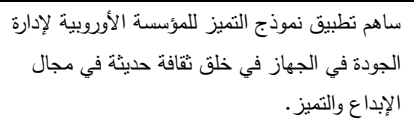 & 5 \\
\hline $75 \%$ & .727 & 3.748 & الدرجة الكلية & \\
\hline
\end{tabular}

\begin{tabular}{|c|c|c|c|c|c|c|}
\hline النتائج & العمليات & والثمواردات & الموظفين & الاستراتيجية & القيادة & المعيار \\
\hline $61 \%$ & $54 \%$ & $54 \%$ & $100 \%$ & $49 \%$ & $57 \%$ & الكوظفون \\
\hline $75 \%$ & $71 \%$ & $100 \%$ & $54 \%$ & 66 & $56 \%$ & والموارد \\
\hline $78 \%$ & $100 \%$ & $71 \%$ & $54 \%$ & $48 \%$ & $53 \%$ & العمليات \\
\hline $100 \%$ & $78 \%$ & $75 \%$ & $61 \%$ & $56 \%$ & $64 \%$ & الننائج \\
\hline
\end{tabular}

جدول رقم (10): مستوى ثقافة التميز في الجهاز وفق نموذج EFQM.
يتبين من الجدول رقم (1') وجودُ ارتباطٍ قوي للعمليات

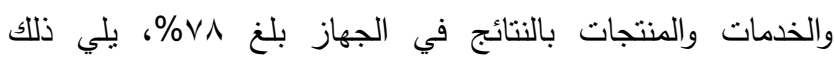

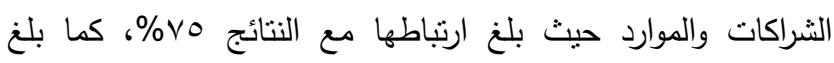

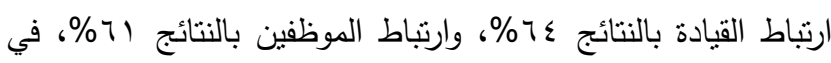

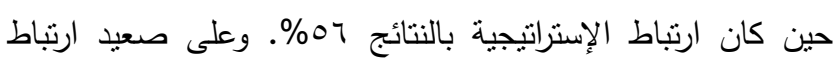

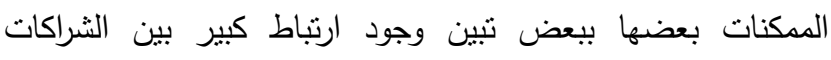

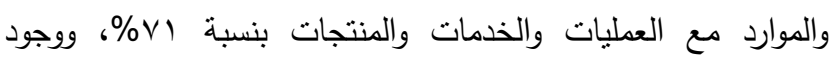

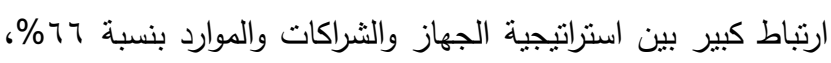

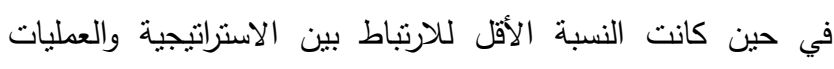

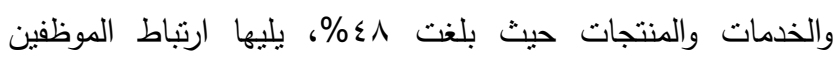

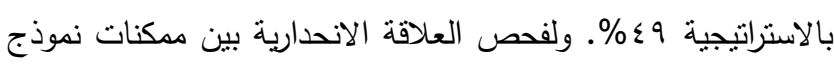
التميز للمؤسسة الأوروبية لإدارة الجودة (المتغيرات المستقلة) ونتائجه

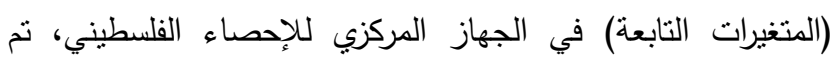

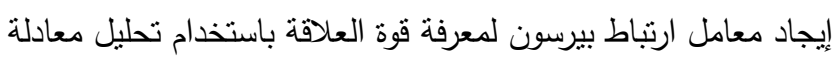

خط الانحدار كما في الجدول رقم (ri إ).

جدول رقم (r ا): ملخص النموذج باستخدم تحليل معادلة خط الاندار.

\begin{tabular}{|c|c|c|c|c|}
\hline $\begin{array}{c}\text { Std. Error } \\
\text { of the Estimate }\end{array}$ & $\begin{array}{c}\text { Adjusted } \\
\text { R Square }\end{array}$ & $\begin{array}{c}\text { R } \\
\text { Square }\end{array}$ & R & النمولئ \\
\hline .20523 & .719 & .733 & .856 & القيادة \\
\hline
\end{tabular}

ويظهر لنا قوة العلاقة بين ممكنات نموذج EFQM ونتائجه في الجهاز والتي بلغت بی,، ، كما بلغ مقار تفسير المتغيرات

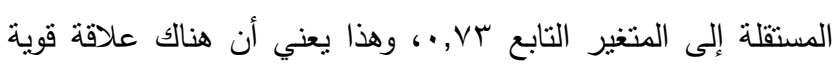
بين الممكنات والنتائج. ولفحص الدلالة الإحصائية لهذه العلاقة نم الثان

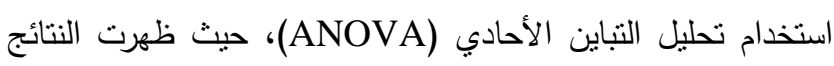

\begin{tabular}{|c|c|c|c|c|c|}
\hline الإحصائية & دالة F & المربعات & درجات & المربعات & Model \\
\hline \multirow[t]{3}{*}{.000} & 51.630 & 2.175 & 5 & 10.873 & الانحدار \\
\hline & & .042 & 94 & 3.959 & البواقي \\
\hline & & & 99 & 14.832 & المجموع \\
\hline
\end{tabular}
كما يلي:

جدول رقم (T ()): ملخص النموذج باستذام تطليل معادلة خط الانحدار. 
النماذج العالمية ويضعها ضمن خططه المستقبلية على الدوام، وأن الجهاز قد أدرج نموذج EFQM ضمن خطته المستقبلية، وهذا يدل

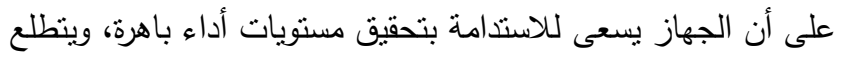

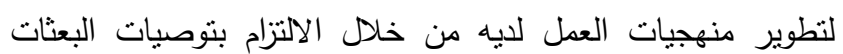
الدولية للجهاز والتي جاءت بنسبة 10\% وهي نسبة عالية جدا يعمل الجهاز على تعزيزها واستدامتها على الدوام.

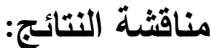

أظهرت النتائج نوافر المدكنات لنموذج EFQM في الجهاز المركزي للإحصاء الفلسطيني بدرجة كبيرة من خلال معايير وممكنات

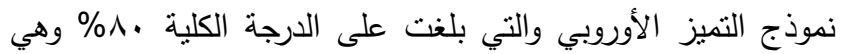

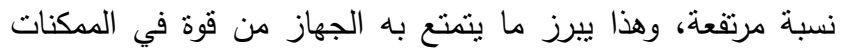
والمتمنلة بالعطليات والمنتجات والخدمات التي يقدمها للجمهور

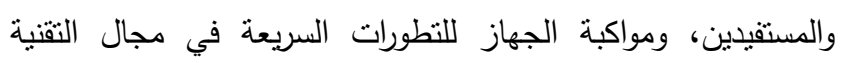
والتكنولوجيا، وتمتعه بمستويات عالية من التخطيط واستعراض نتائج

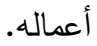

خرجت الدراسة بوجود علاقة قوية ذات دلالة إحصائية بين مكنات نموذج EFQM ونتائجه في الجهاز المركزي للإحصاء

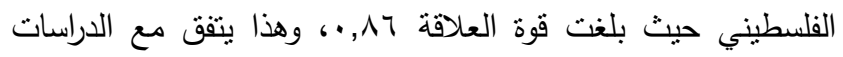
السابقة لكل من دراسة جرار ودراسة Gorji و Siami ودراسة - Bou Llusar وارتباط قوي بين ممكنات ونتائج نموذج EFQM، ويعزو الباحثان قوة

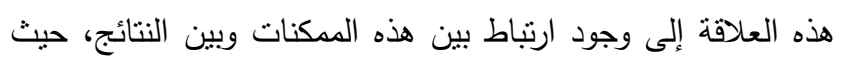

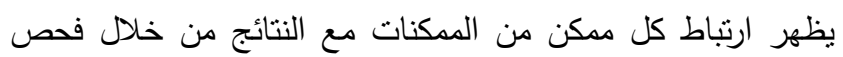
الارتباط الثائي كما في الثكل رقم (Y).

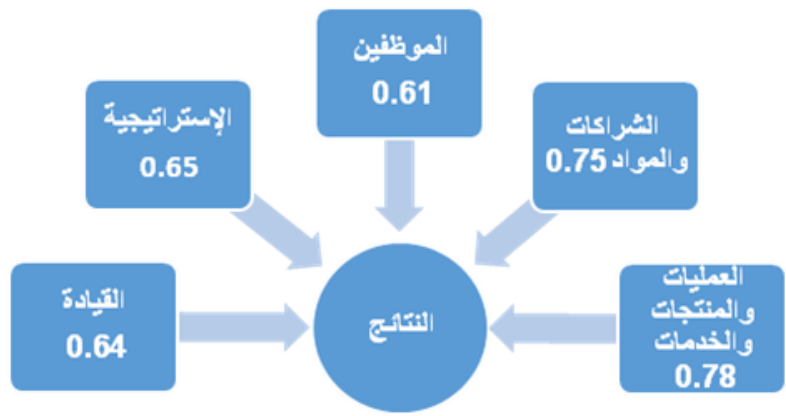

شكل رقم (ץ): الارتباط بين ممكنات ونتائج نموذج EFQM في الجهاز. المصدر: من تصميم الباحثان

ويظهر لنا من الثكل السابق أن معيار العطليات والمنتجات

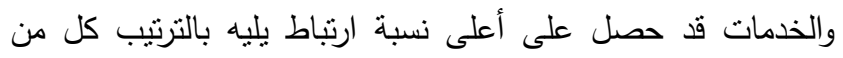
الشراكات والموارد ثم القيادة ثم الموظفون ثم الاستراتيجية، وهذا يتفق تماما مع دراسة Gorji و Siami والتي أثنارت إلى أن أولوية فعالية
يتبين من الجدول رقم (10) أن الدرجة الكلية لدستوى ثقافة التميز وفق نموذج EFQM في الجهاز المركزي للإحصاء الفلسطيني

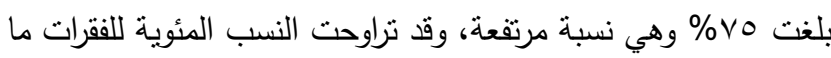

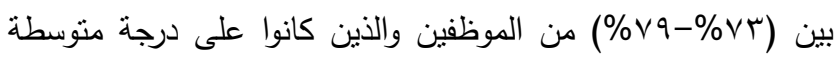
من الاتفاق على أنه يوجد لديهم نقافة وبيئة ندعم التمبز في الجهاز

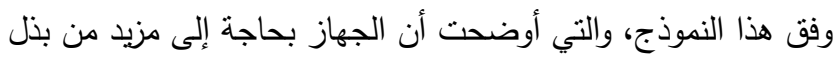

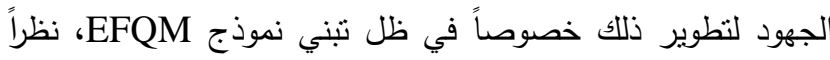

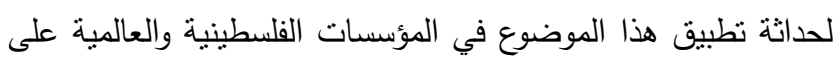
حد سواء، وبالتالي يجب على الجهاز تعزيز ثقافة مدكنات هذا النموذج بين موظفيه بشكل أكبر . النتائج المتعلقة بالسؤال الرابع: ما هي رؤية الجهاز المركزي لوني

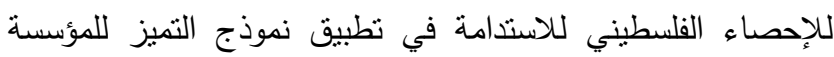
الأوروبية لإدارة الجودة EFQM والاستدامة في تحقيق مستويات باهرة

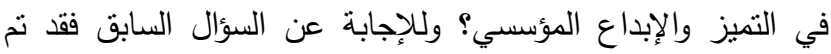

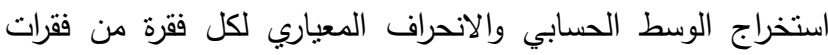
محور الاستدامة كما في الجدول رقم (17).

جدول رقم (1) 1): روئة الجهاز في الاستدامة في تطبيق نموذج EFQM.

\begin{tabular}{|c|c|c|c|c|}
\hline 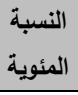 & المعياري - المراف & المستوسط & الفقرات & الرق \\
\hline $89 \%$ & .540 & 4.46 & يستخوم الجهاز تقنيات حديثة وتكنولوجيا & 1 \\
\hline $89 \%$ & .624 & 4.43 & يتم إعداد تقارير شهرية وسنوية لأهم إنجازات & 2 \\
\hline $87 \%$ & .562 & 4.37 & 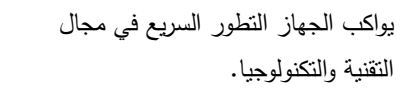 & 3 \\
\hline $86 \%$ & .581 & 4.31 & يبيثث الجهاز دائماً عن مجالات التميز & 4 \\
\hline $86 \%$ & .595 & 4.30 & 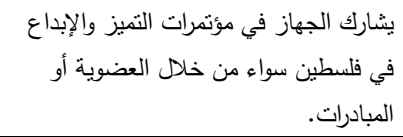 & 5 \\
\hline $86 \%$ & .628 & 4.30 & الجتابع الإدارة العامة للتخطيط والتطوير في & 6 \\
\hline $86 \%$ & .686 & 4.29 & فاعل. ترويج مخرجات الجهاز الإحصائية بشكل & 7 \\
\hline $85 \%$ & .601 & 4.23 & لديهل الدولية خلال الالتزام بتوصيات النطوير منهجيات العمل & 8 \\
\hline $87 \%$ & 0.602 & 4.33 & الدرجة الكلية & \\
\hline
\end{tabular}

يتبين من الجدول رقم (7 (1) أنّ الدرجة الكلية للاستدامة في

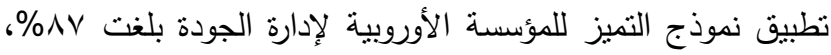

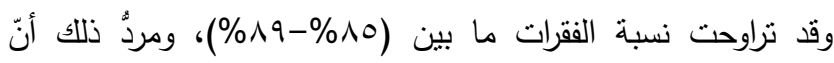

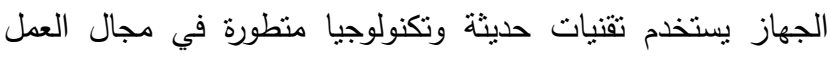
بشكل قوي وكبير ويقوم بإعداد التقارير الثهرية والسنوية لأهم إنجازات

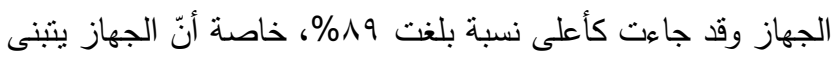


ارتباط بالنتائج، بل يعني عدم وجود علاقة مباثرة رئيسة نؤثر على نتائج الأداء الكلي للمنظمة، ويعزو الباحثان عدم وجود هذه العلاقة

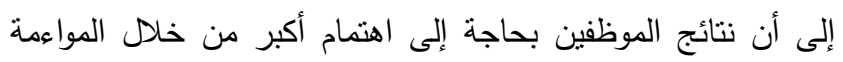
بين الأهداف الثخصية للموظفين وأهداف الجهاز، وتفهم الجهاز العوامل المؤثرة في نتائج الموظفين والتي تؤثر على مؤشرات الأداء

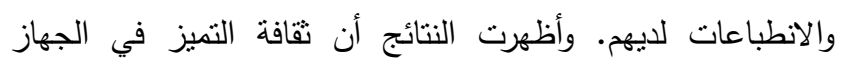

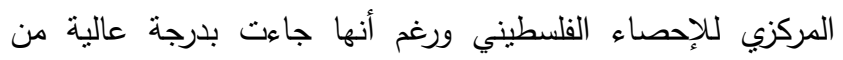

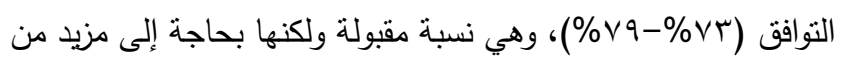
بذل الجهود لتطوير ذلك خصوصاً في ظل تنبي المؤسسة لنموذج

.EFQM

ويعزو الباحثان ظهور هذه النسبة نظرا لنقافة الجهاز نحو

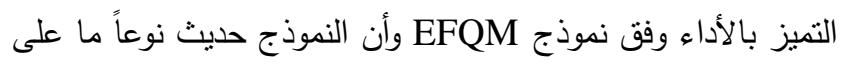
منظماتتا المحلية، وأن دراسة وفهم هذا النموذج يتطلب تتفيذ دورات تدريية متخصصة في نموذج EFQM، وبسبب ندرة الخبرات في هذا

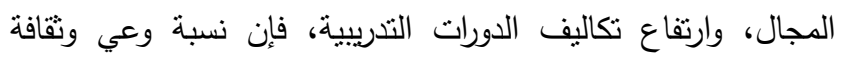

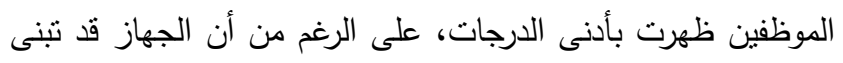

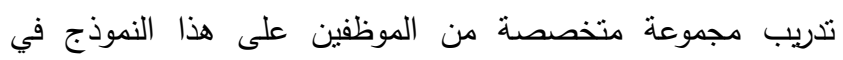

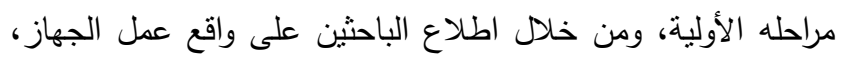

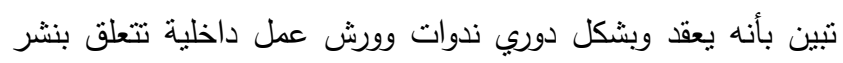
ثقافة التميز والإبداع وتوعية الموظفين بهذا النموذج.

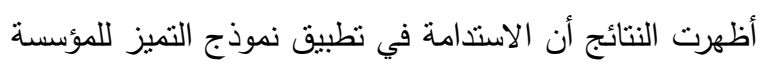

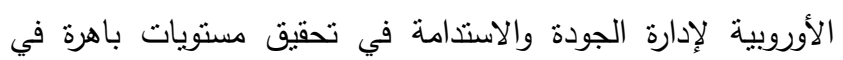

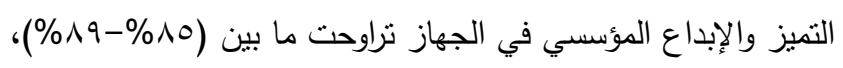
وهي نسبة مرتفعة نظرا لأن الجهاز يستخدم تقنيات حديثة وتكنولوجيا منطورة في مجال العمل بشكل قوي وكبير.

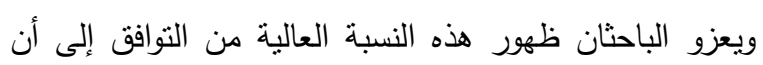
الجهاز يتبنى النماذج العالمية ويضعها ضمن خططه المستقلية دوماً،

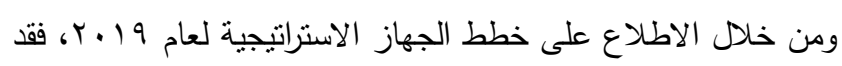
تبين إدراج نموذج EFQM في الخطة، ولم ينوقف الجهاز فقط عند الدال

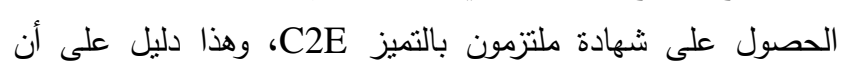

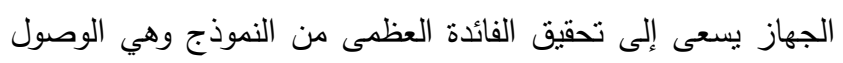
إلى مسنويات أداء باهرة تقوق النوقعات.

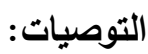

في ضوء نتائج الدراسة يوصي الباحثان بالآتي: الاهتمام بوضع استراتيجيات على المستوى يين التكتيكي لالتئي والتتغيلي، وذلك لتحقيق مستويات أعلى من التميز .

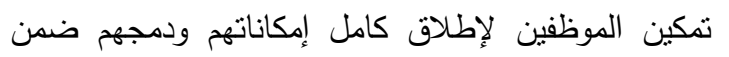

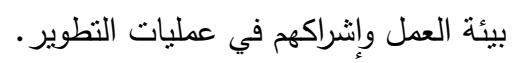

معايير التمكين على الأداء جاءت بمعايير العمليات والثركاء والموارد والقيادة والناس والسياسات والاستراتيجيات على الترتيب. ويعزو الباحثان حصول معيار العمليات على أعلى نسبة ارنباط

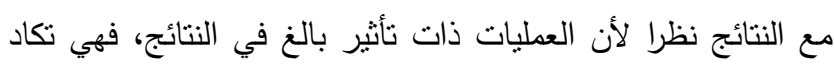
تمثل القلب النابض في الجهاز، ويعكس أداء القيادة والاستراتيجية

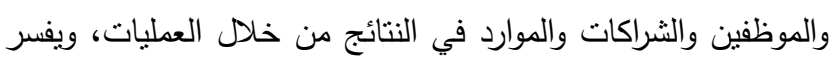
حصول هذا المعيار على أعلى نسبة ارتباط في الجهاز كون الجهاز

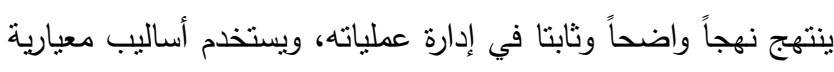

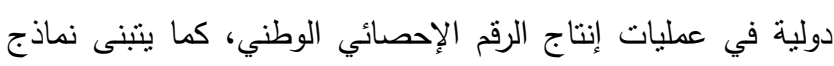

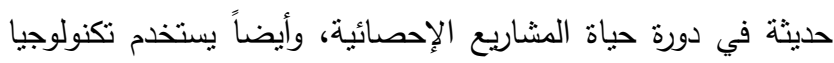

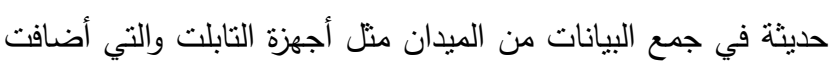
نوعاً من المصداقية والثبات في عمليات إنتاج الرقم الإحصائي.

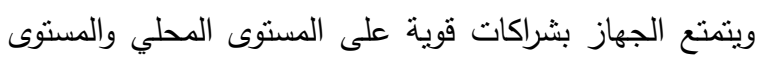

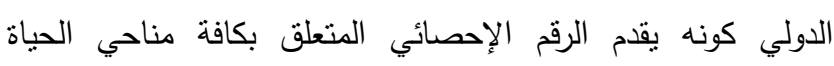
(الاقتصادية، الاجتماعية، السياسية، الإنسانية، السكانية، الجغرافية)

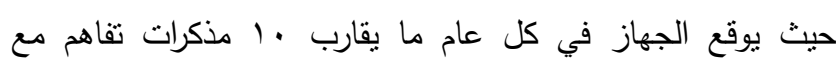
مؤسسات من القطاع العام والخاص. أما حصول الاستراتيجية على أقل نسبة ارتباط بالنسبة للمعايير

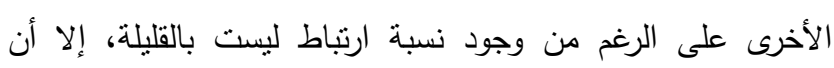

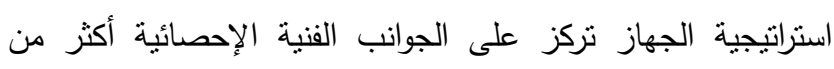

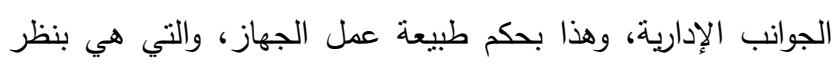

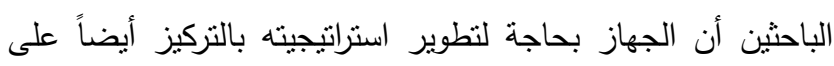
جوانب العمل الإدارية وذلك لتحقيق مسنويات أعلى من التميز .

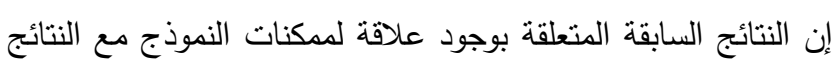
اتققت عليها معظم الدراسات السابقة، وعدم وجود علاقة ذات دلالة التهات

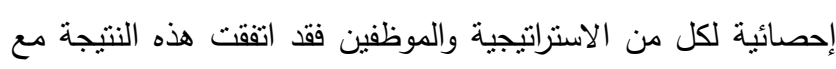
دراسة Bou-Llusar و آخرون، والتي أنثارت إلى أن مجموعة معايير التككين ترتبط ارتباطًا وثيقًا بمجموعة معايير النتائج باستثناء معايير أنياء السياسة والاستراتيجية. ويعزو الباحثان ظهور النتيجة السابقة إلى أن دور القيادة في

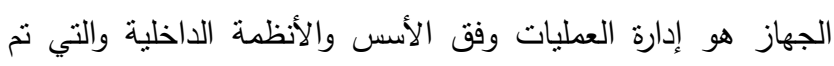
الإطلاع عليها والموثقة على الإنترانت الداخلي الخاص بالإن بالجهاز والتي

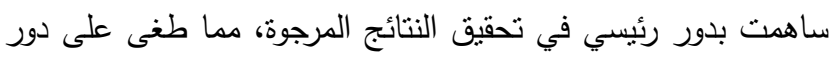
استراتيجية الجهاز بشكل مباشر في تحقيق ذلك، كما تم الإثارة سابقاً إلى أن استراتيجية الجهاز بشكل رئيس تركز على الجوانب الإحصائية الفنية بنسبة أكبر من الجوانب الإدارية، كما أن استراتيجية الجهاز

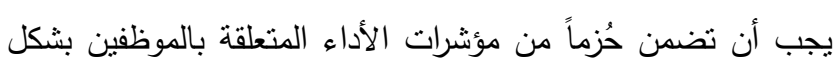

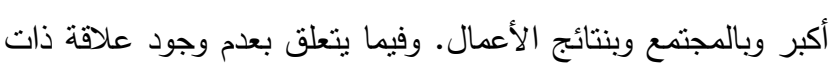

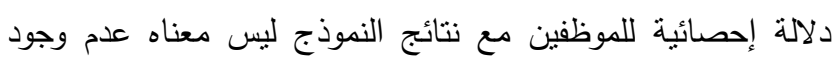


published). Khalel university. Palestine. P. 25.

4. Al-Jubouri, Mayser Ibrahim (2008): Expected Roles of the International Quality Awards in Sustaining Excellence and Competitiveness - a reference to the King Abdullah II Award for Excellence. Encyclopedia of excellence and global civilization. $\mathrm{P} 2$ 2. The site of the Encyclopedia of Excellence and civilization on the Facebook page browse on $01 / 10 / 2018$. https://www.facebook.com/tamayoz.pal/p osts/566082363421521/

5. AL-Nokhba Company for Innovation Development and Management Consultants- IDMC (2017): Evaluation and qualification according to the European Excellence Model EFQM Palestinian Central Bureau of Statistics. AL-Nokhba Company site. Browsing history 01/10/2018. http://www.idmc.ps/en

6. Al-Sulami, Ali (2002): Management of Excellence - Models and Techniques of Management in the Knowledge Age. Cairo: Dar Gharib for printing, publishing and distribution. P. 12.

7. Al-Tai, Raad Abdullah and Issa Qadada (2008): Total Quality Management. Vol 1, E1. Amman: Dar Al Yazouri Scientific Publishing \& Distribution. P. 372.

8. El-Meligy, Reda (2012): Management of Organizational Excellence between Theory and Practice. Vol 1, E1. Beirut: Books World for Printing, Publishing and Distribution. P. 387.

9. Haidar, Zaid and Ali Al-Sudani (2016): Performance Evaluation according to the Staff Standards and Employee Results of the European Excellence Model EFQM 2013 - Case Study in the Office of the Inspector General and Ministry of Health. Journal of Economic and Administrative Sciences - University of Baghdad. Vol 23. Version 98. 175-196.

10. Ghanem, Amjad (2014): Palestinian Central Bureau of Statistics SelfAssessment Report using the European Excellence Model EFQM. (Unpublished). Ramallah: Elite Management Consulting Company. P. 6.

11. Jarrar, Thiab (2013): The relationship between the elements of performance excellence and its results in the Palestinian pharmaceutical industry.

$$
\begin{aligned}
& \text { العمل على تعزيز مواءمة الأهداف الثخصية للموظفين بما } \\
& \text { يتلاءم مع أهداف الجهاز وتقهم الجهاز للعوامل المؤثرة في بهائ }
\end{aligned}
$$

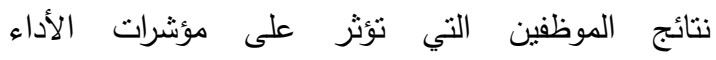

$$
\begin{aligned}
& \text { والانطباعات لديهم. } \\
& \text { نظرا لحداثة نطبيق نموذج EFQM في الوطن العربي فإنه } \\
& \text { يجب تعزيز ثقافة النموذج، لما له من دور يساهم في }
\end{aligned}
$$

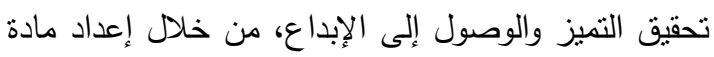

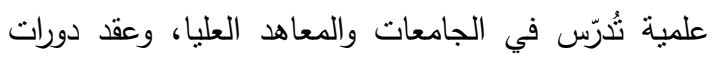

$$
\begin{aligned}
& \text { تدريبية لذلك. } \\
& \text { على القائمين على نموذج لعFM للمؤسسة الاوروبية } \\
& \text { وضع معايير فرعية لكل من معياري القيادة والاستراتيجية } \\
& \text { بصورة منفصلة وواضحة بعيدة عن التداخل بين السياسات } \\
& \text { التي تنتهجها القيادة وبين الاستراتيجية الموضوعة، والتي } \\
& \text { أثنارت لها نتائج هذه الدراسة والدراسات السابقة المذكورة في } \\
& \text { هذه الدراسة. } \\
& \text { • على القائمين على نموذج EFQM وضع معايير تتسم } \\
& \text { بالمرونة لنطويع النموذج بصورة مباشرة مع قطاع الخدمات } \\
& \text { والقطاعات الأخرى خاصة أنّ النموذج بمفاهيمه ومبادئه } \\
& \text { ومعاييره ومنطقه موجه لقطاع الأعمال والثركات الربحية }
\end{aligned}
$$

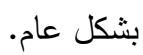

$$
\begin{aligned}
& \text { دعم توجه الجهاز المركزي للإحصاء الفلسطيني إلى تحقيق }
\end{aligned}
$$

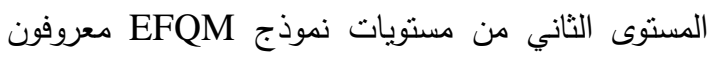

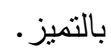

$$
\begin{aligned}
& \text { إيلاء موضوع قياس انطباعات المجتمع وجمهور المستقيدين } \\
& \text { للخدمات التي يقدمها الجهاز الاهتمام اللازم. }
\end{aligned}
$$

\section{References:}

\section{Arabic References:}

1. Abdul Wahab, Nadia and Sanaa Suleiman (2016): Using the European Excellence Model EFQM in Evaluating the Performance of Organizations - An Applied Research in Al-Numan General Hospital. Journal of Dinars. F1. Eighth Edition. 236-288.

2. Al-Hilalat, Saleh Ali Odeh (2014): Management of Excellence Modern Practice in the Management of Business Organizations. Amman / Jordan: Wael Publishing House. P. 56.

3. Al-Jabari, Taghreed (2009): The Role of the Department of Excellence in Developing the Performance of Higher Education Institutions in the West Bank. (A magister message that is not 
Reliability Management. Vol 22 Issue 4. $337-353$.

18. EFQM Organization (2013): The European Foundation for Quality Management (EFQM) Excellence Model. Belgium/ Brussels: EFQM. P4-P26.

19. EFQM Organization Website (2018): OUR HISTORY. Browsing history 27/10/2018.

http://www.efqm.org/index.php/about-us/ourhistory/

20. Gorji, Mohammadbagher \& Sahar Siami (2011): Self-assessment with regard to EFQM model and the relationship between its criteria and Organization's Performance. Australian. Journal of Basic and Applied Sciences. 5(12). 153161.

21. Kanji, G.K (2002): AN Integrated Apparels Business Excellence- Total Quality Management. Vol. (12), No. (2). P701.

22. Kinji, G.K (2001): Kinji Business Scorecard- Total Quality Management. Vol. (12), No. (6). Is7-8. P701.

23. Okland, John (2001): Total Organizational Excellence- Achieving World-class Performance. LONDON AND NEW YORK: British Library Cataloging in Publication Data. Worth Heinemann USA. P3.

24. Palestinian Central Bureau of Statistics (2016): EFQM Committed to Excellence Submission. (Unpublished). Ramallah Palestine.P5.

25. Pinar, $M \&$ T Girard (2008): Investigating the Impact of Organizational. P29.

26. Vukomanovic, Mladen, Mladen Radujkovic \& Maja Marija Nahod (2014): EFQM excellence model as the TQM model of the construction industry of southeastern Europe. Journal of Civil Engineering and Management. Vol 20. 70-81. P70.
Journal of the Islamic University for Economic and Administrative Studies. Vol 21. Second Issue. P263-295.

12. Sabaghneh, Abdullah, Majid Al-Shaka'a, Bashar Soudah and Raya Abdelhadi (2010): Application of the Institutional Assessment Tool for the European Excellence Model EFQM. (Unpublished bachelor research). An-Najah National University. Nablus. P. 3.

13. Shawki, Qubtan (2009): Management of Excellence - Modern Philosophy of the Success of Organizations in the Era of Globalization and Competition. The Fourth International Forum on Competition and Competitive Strategy for Industrial Organizations outside the Hydrocarbons Sector in the Arab Countries. Hassiba Ben Bouali University in Chlef. Algeria: Laboratory of Globalization and the Economies of North Africa. P. 8.

14. Palestinian Central Bureau of Statistics (2018): Annual Report 2017 "Year of the Third Census of Population, Housing and Establishments". Ramallah. P. 33.

15. Palestinian Central Bureau of Statistics (2015): Organizational Structure of the Palestinian Central Bureau of Statistics. Ramallah. P. 9.

16. Yacoub Mousa, Mohammed (2012): The impact of the application of standards of excellence and business ethics in the results of business - a study of the reality of companies operating quality systems and excellence in the industrial city of Giad. (Unpublished doctoral thesis). University of Sudan. Sudan.

\section{English References:}

17. Bou-Llusar, J. Carlos, Ana B. EscrigTena, Vicente Roca-Puig \& Inmaculada Beltrán-Martín (2005): To what extent do enablers explain results in the EFQM excellence model?- An empirical study. International Journal of Quality \& 


\section{استبانة بعنوان \\ العلاقة بين ممكنات نموذج التميز للمؤسسة الأوروبية لإدارة الجودة "EFQM" ونتائجه \\ في الجهاز المركزي للإحصاء الفلسطيني}

السيدات والسادة الكرام موظفي الجهاز المركزي للإحصاء القلسطيني،،

السلام عليكم ورحمة الله ويركاته

نقوم بعمل بحث حول العلاقة بين ممكنات نموذج التميز للمؤسسة الأوروبية لإدارة الجودة "EFQM" ونتائجه في الجهاز المركزي للإحصاء

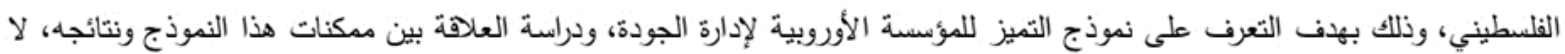

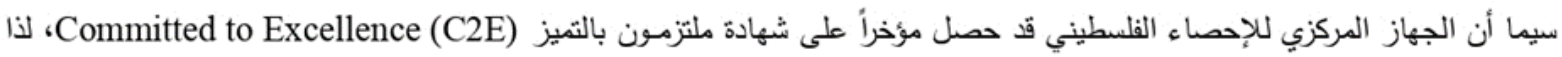
يرجو الباحثان من حضرتكم التكرم بتعبئة هذه الاستبانة وذلك بما بثوافق مع وجهة نظركم وبما يثوافق بالواقع في الجهاز ، علماً بأن بيانات الدراسة هي لأغراض البحث العلمي فقط، وسيتم الحفاظ على سريتها. وتفضلوا بقبول فائق الاحترام ،،

$$
\text { أ. أعبل العداد: جلاديطي }
$$

القسم الأول: المعلومات العامة

\begin{tabular}{|c|c|c|c|c|c|}
\hline & & & & 口 أنثى & ألجنس \\
\hline & & & & & الفئة الوظيفية \\
\hline \multirow[t]{4}{*}{ 口 الفئة الخامسة } & 口 الفئة الرابعة & 口 الفئة الثالثة & 口 الفئة الثانية & 口 الفئة الأولى & 口 الفئة العليا \\
\hline & & & & & مجال العمل \\
\hline & & & [ـ الإدارات الاحصائي & & 口 الإدارات المسا \\
\hline & & & & هاز & سنوات الخبرة في \\
\hline$\square$ (15) سنة فأكثر & ن 15) سنة & $\square$ & من 10) سنوات. & $\square$ & 口 5 سنوات فأولّ \\
\hline
\end{tabular}
الرجاء وضع اشارة ( ل) في مربع الاجابة التي تنطبق عليك.

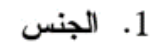




\section{القسم الثاني: فقرات الاستبانة}

يرجى الإجابة على فقرات هذا القسم بوضع إشارة (X) مقابل كل عبارة من العبارات الآتية:

\begin{tabular}{|c|c|c|c|c|c|c|}
\hline بشير & غوافير & محايد & موافق & موافق & 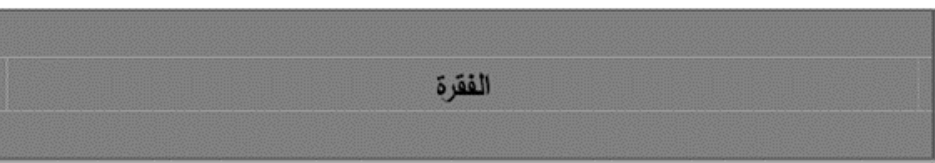 & الرقم \\
\hline \multicolumn{7}{|c|}{ أولاً: ثقافة التميز والإبداع } \\
\hline & & & & & هذاك دراية ووعي لدى الموظفين في الجهاز بمفهوم التميز . & 1 \\
\hline & & & & & لاى الجهاز بيئة عمل تدعم وتشجع الإبداع والتميز. & 2 \\
\hline & & & & & أشعر بأنني مشارك في عملية النطوير القائمة في الجهاز . & 3 \\
\hline & & & & & لتوجيق ألفي معرفة بنموذج التميز للمؤسسة الأوروبية لإدارة الجودة من خلال استخدامه & 4 \\
\hline & & & & & حليثة في مجال الإبداع والتمبز تطبيق نموذج التمؤسنة الأوروبية لإدارة الجودة في الجهاز في خلق ثقافة & 5 \\
\hline
\end{tabular}

ثانياً: ممكنات نموذج التميز للمؤسسة الأورويية لإدارة الجودة

*

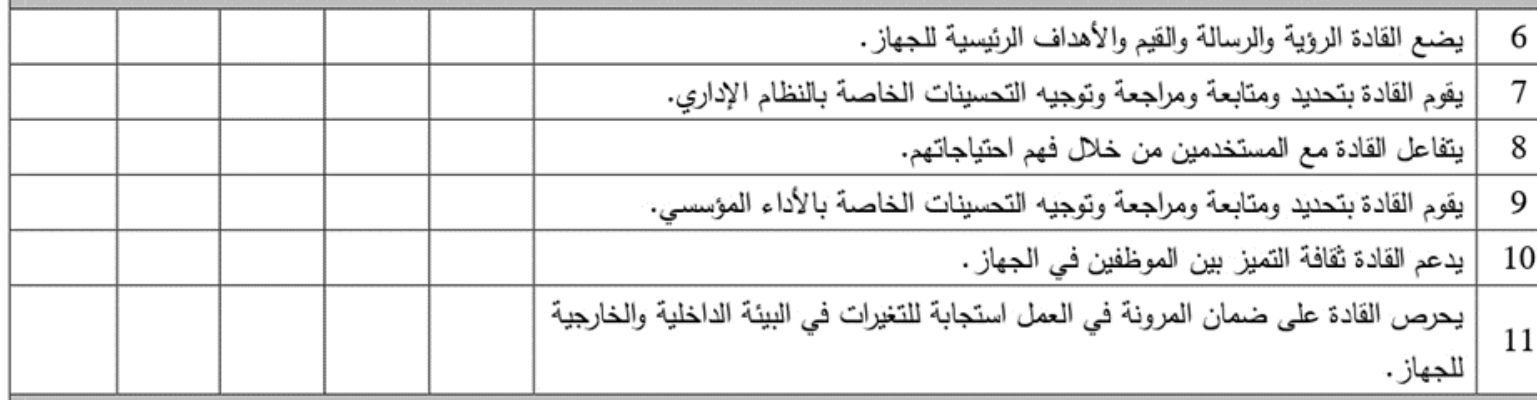

*

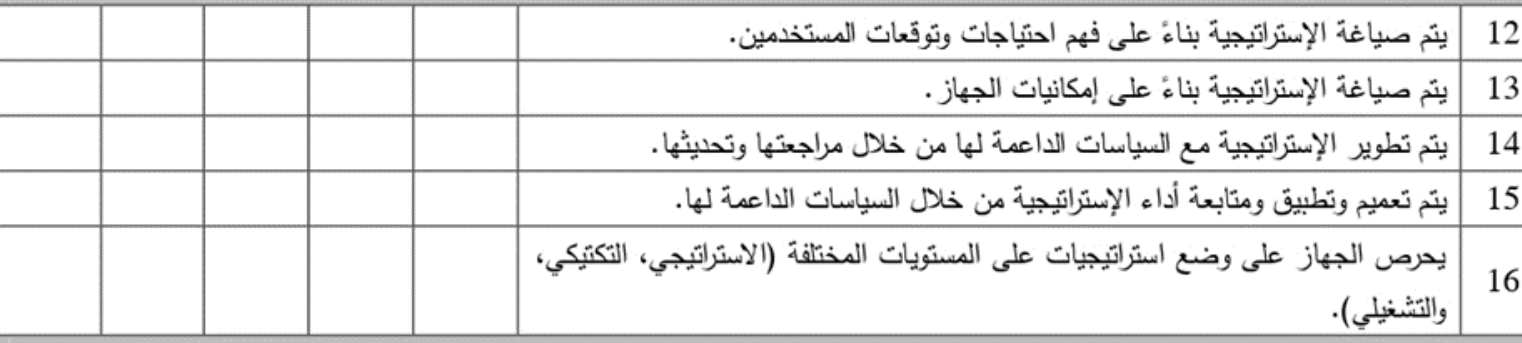

* * الموظفون

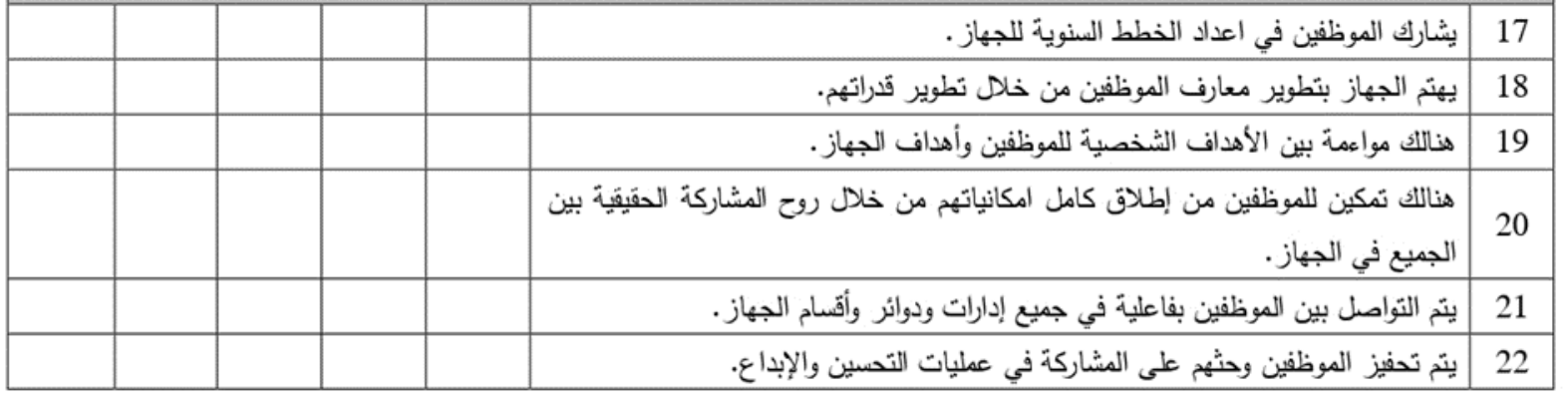




\begin{tabular}{|c|c|c|c|c|c|c|}
\hline غوافير & 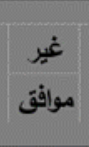 & محايد & 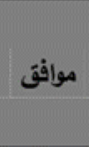 & بشدافة & الفقرة & الرقم \\
\hline \multicolumn{7}{|c|}{ - م الثراكات والموارد } \\
\hline & & & & & 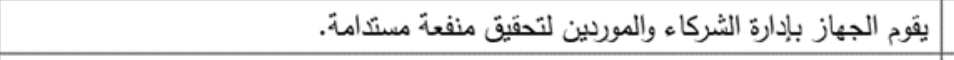 & 23 \\
\hline & & & & & | يقوم الجهاز بإدارة المباني والمعدات والمواد والموارد الطبيعية بطريقة مستدامة من خلال & 24 \\
\hline & & & & & | يقوم الجهاز بإدارة التقنية والتكنولوجيا لدعم وتتفيذ الاستراتيجية. & 25 \\
\hline & & & & & | يتثم تزويد القادة في الجهاز بمعلومات دقيقة وكافية توفر لهم الدعم الملاثم في صناعة & 26 \\
\hline & & & & & ليتم إدارة المعلومات والمعرفة لبناء قدرات الجهاز في الجوانب الفنية والمساندة. & 27 \\
\hline \multicolumn{7}{|c|}{ • العمليات والمخرجات الاحصائية } \\
\hline & & & & & | يتم تصميم العمليات وإداراتها بهدف تعظيم القيمةً لصالح جميع المستخدمين. & 28 \\
\hline & & & & & | ليتم تطوير المخرجات الإحصائية التي يقدمها الجهاز لتحقيق القيمة المثلى لصالح & 29 \\
\hline & & & & & | يتّ ترويج مخرجات الجهاز الإحصائية بشكل فاعل. & 30 \\
\hline & & & & & 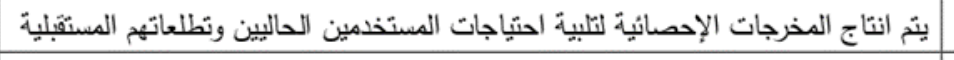 & 31 \\
\hline & & & & & | يهتم الجهاز بابدارة علادات المستخدمين وتعزيزها من خلال بناء وتطوير حوار متواصل & 32 \\
\hline
\end{tabular}

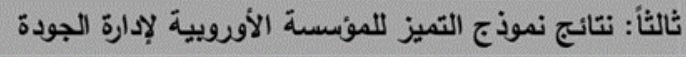

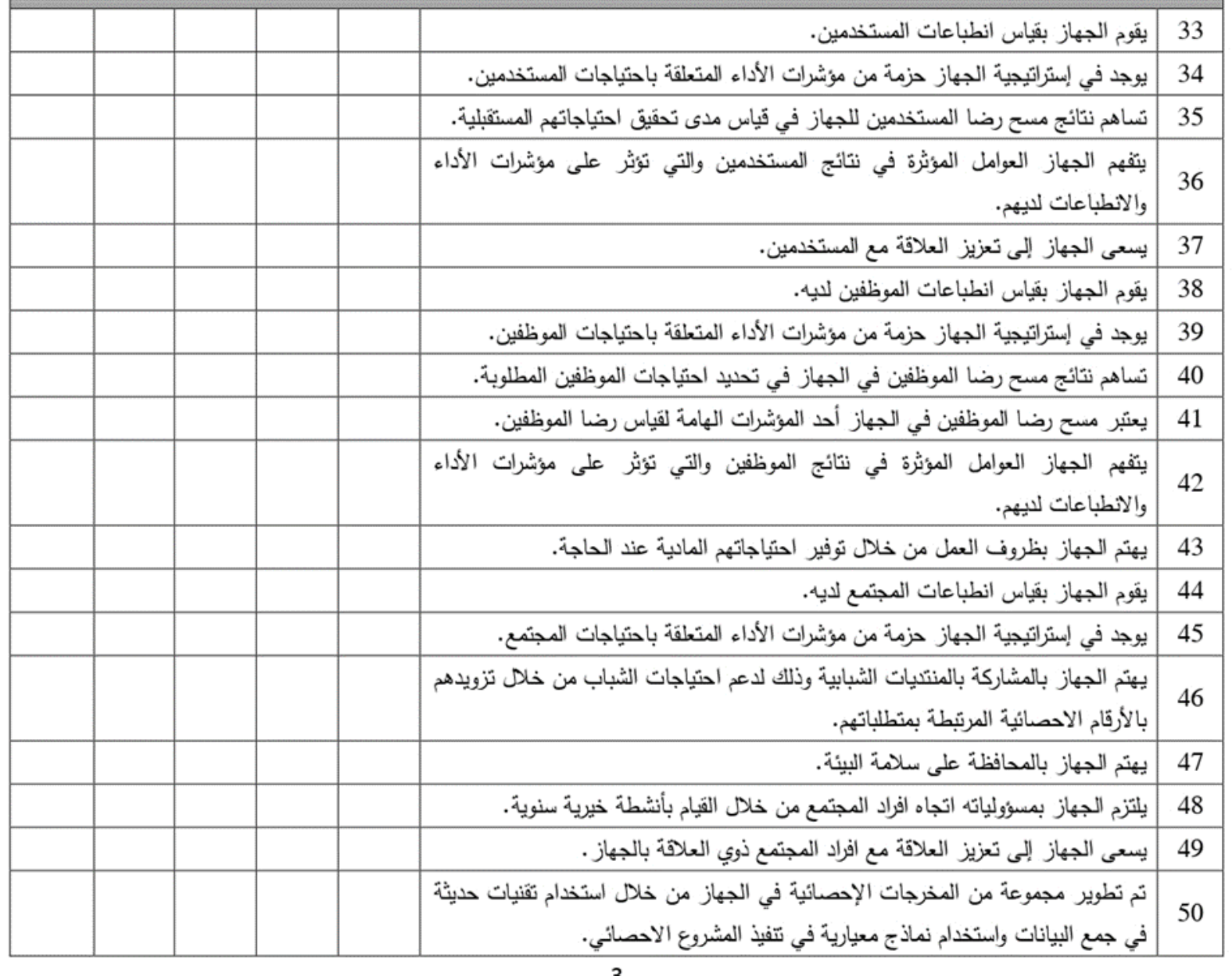




\begin{tabular}{|c|c|c|c|c|c|c|}
\hline بشير بوافق & موافق & محايد & موافق & 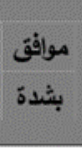 & الفقرة & الرقم \\
\hline & & & & & 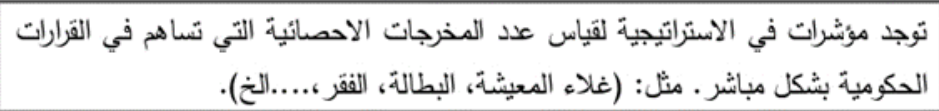 & 51 \\
\hline & & & & & 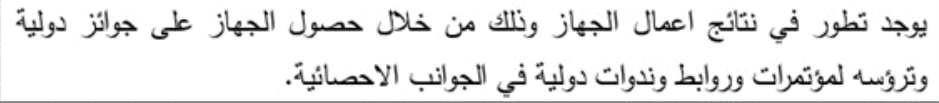 & 52 \\
\hline & & & & & تتابع الادارة العامة للتخطيط والتطوير في الجهاز تطبيق الاستراتيجيةٌ بشكل دوري. & 53 \\
\hline & & & & & هنالك مشاركةة فاعلة لموظفي الجهاز في برامج العمل واللجان والمشاريع في المنظمات & 54 \\
\hline & & & & & ينتم اعداد تُقارير شهرية وسنوية لأهم انجازات الجهاز. & 55 \\
\hline \multicolumn{7}{|c|}{ 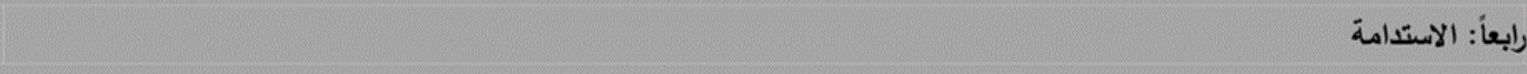 } \\
\hline & & & & & يستخدم الجهاز تقنيات حديثة وتكنولوجيا منطورة في مجال جمع البيانات. & 56 \\
\hline & & & & & يواكب الجهاز التطور السريع في مجال الثقنتية والتكنولوجيا. & 57 \\
\hline & & & & & الدولية للجهاز الجهاز دومأ لنطوير منهجيات العمل لديه من خلال الالتزام بتوصيات البثثات & 58 \\
\hline & & & & & المشاركة فيها أو تبنيها. & 59 \\
\hline & & & & & خلال المبادرات الثخصية. مئتمرات التميز والإبداع في فلسطين سواء من خلال العضوية أو من & 60 \\
\hline
\end{tabular}

أيه اقتراحات أو ملاحظات أخرى .

$$
\text { شاكرين لكم حسن تعاونكم ، ، }
$$

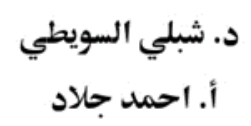

